\title{
Demokratik Toplumlarda Halkın Yönetime Katılımı: Yönetime Katılım ve Yönetişim İlişkisi
}

\author{
Public Participation in Democratic Societies: Relationship Between Participation and Governance
}

\section{Ferit İZCi}

Prof. Dr., Van Yüzüncü Yıl Üniversitesi,

İ̈BF, Кати Yönetimi Bölümü,

ferit.izci@yyu.edu.tr

https://orcid.org/0000-0001-6383-1280

\section{Mehmet SARITÜRK}

Dr. Ögrr. Üyesi, Adlyaman Üniversitesi, İ̈BF, Кати Yönetimi Bölümü, mehmetsariturk@hotmail.com https://orcid.org/0000-0002-9054-8170
Makale Başvuru Tarihi: 18.12.2019

Makale Kabul Tarihi: 29.12.2019

Makale Türü: Araştırma Makalesi

\section{ÖZET}

Anahtar

Kelimeler:

Yönetişim,

Halkın Katılımı,

Katılimcl

Yönetişim,

Keywords:
Governance,
Public Participation,
Participatory
Governance,

Keywords:

Governance,

Governance,
Katılım olgusu tarihin her döneminde ve yönetimin her aşaması için geçerli olan bir gerçekliktir. Modern toplumların hem meşruiyetini hem de belirleyiciliğini sağlayan şey katılım olgusudur. Özellikle, İki kutuplu dünya düzeni, Avrupa ve ABD'nin kapitalizme dayall liberal siyasal sistemlerinin ekonomik ve siyasal sonuçları II. Dünya Savaşı'ndan sonra iktidarların meşruiyetinin ve devamlılı̆̆ının katılım olgusuna dayandı̆̆ını göz önüne sererek kavramın yeniden tartışılmasına ve daha fazla uygulama alanı bulmasına neden olmuştur. Demokratik toplumlarda halkın hem siyasi hem de idari anlamda yönetime katılması esastır. Yönetişim ise neo-liberal anlayışın uygulamalarındandır ve yeni bir karar alma ve katılım anlayışını ifade etmektedir. Siyasi ve idari sistemin başlangıcından bu yana devam eden katılım olgusunun yönetişim yaklaşımı ile ilişkisini anlamak sistemin devamlılığını anlamak bakımından önemlidir. Bu yüzden çalışmada, genel olarak yönetime katılma kavramı irdelenmiş, yönetime katılma ile yönetişim ilişkisi derinlemesine analiz edilmiştir.

\section{ABSTRACT}

The participation phenomenon has a decisive influence on every social entity at every stage of administration and every period of history. In modern times, the legitimacy and continuity of administrative and political institutions are decisive. The bipolar world order and the economic and political consequences of liberal political systems based on the capitalism of Europe and the USA, has led to the re-discussion and implementation of participation after World War II, taking into account the legitimacy and continuity of the system. Governance is the practice of neoliberal understanding and it expresses the understanding of a new method of decision-making and participation. Understanding the relationship between the governance approach and the involvement of the political and administrative system since the beginning of the system is important in terms of understanding the continuity of the system. 


\section{GIRISS}

Yönetime katılım demokrasinin temel ilkesidir. Seçimler ya da referandumlar için oy kullanma, bürokrasiden istekte bulunma ve kamu politikalarını destekleme, katılımın yaygın ve temel biçimleridir. Katılım olgusunun temelinde toplumun her kesimden gelen büyük bir istek vardır. Ülkede yaşayan sıradan vatandaşlardan tutun, girişimcilere, her türlü sivil ve resmi kuruluşlara kadar her kes, kendilerini etkileyecek olan siyasal kararların ayrıntılarından, karar alınmadan önce haberdar olmak, mevcut proje ve politikalarda aktif biçimde rol almak ve kararlara doğrudan katılmak ister. Halkın yönetime katılımı, yapısal bir konu değildir. Tam aksine, kapsayıcı bir demokrasiye geçişte toplumda sosyo-politik değişime yol açan yapının ve işleyiş̧in yeniden düzenlenmesi ve yapılandırılmasını gerektiren birleşik güç ilişkileri topluluğundan doğmaktadır.

Demokratik toplumlarda, vatandaş katılımı ilkesi neredeyse evrensel bir değer olarak kabul görmekte ve katılımın araçları ve kapsamı sıklıkla da tartışılmaktadır. Yönetime vatandaşın katılımı, geleneksel olarak yönetim hakkındaki bilgilere daha fazla kamu erişimini kolaylaştırmak, vatandaşların haklarını doğrudan etkileyen konularda, vatandaşın görüşünün alınması ve toplumdaki ilgili tüm kesimlerin adil temsili açısından demokratik katılma için gerekli araçları sağlamaktadır. Bu tür araçlar, genellikle standart kurallar, protokoller ve mevzuat ile ilgili düzenlemeleri içermektedir (Aulich, 2009:45).

Son yılların ilginç teorik tartışmalarından birisi de yönetişim kavramı etrafında gerçekleşmektedir. Yönetişim anlayışının temelinde çok aktörlü katılım esas olduğundan dolayı, demokratik yönetimle doğrudan bağlantılıdır. Yönetişimin merkezi hükümetin politika sürecine katkısını nasıl etkilediğine ilişkin önemli çalışmalar, "yönetişim" ile neyin kastedildiği ve hükümetteki etkisi açısından farklı analitik yorumlara ilişkin farklı tanımlar bulunmaktadır (Marinetto, 2003:592). Yönetişim paradigmasına geçiş konusunda konuşmak oldukça ironiktir. Oysa hükümetin ve kamu yönetiminin amacı yönetişimdir. Siyasetin ve idarenin çıktıları farklı süreçlerin ürünüdür. Umumiyetle yönetişimin "kamu ve özel sektör arasındaki sinırların bulanık hale geldiği yönetim stillerinin geliştirilmesi" anlamına geldiği dönem için tanım üzerinde anlaşmaya varılmıştır. Yönetişimin özü, hükümetin otoritesine ve yaptırımlarına başvurmayacak yönetim mekanizmaları üzerine odaklanmaktadır. Bu, çeşitli yönetime ve birbirlerini etkileyen aktörlerin etkileşimidir (Al-Habil, 2011:124). Tek bir merkezin olmadığı ama çok sayıda merkezin olduğu anlamına gelir. Ağların özerkliği önemli olduğundan, egemenlik yetkisine sahip bir güç bulunmamaktadır Umumiyetle yönetmek kelimesinin eşanlamlısı veya yönetme etkinliğini nitelemek için kullanılan bir terimdir. Yönetişim kavramı, 1980'lerin sonlarından ve 1990'lardan itibaren yeni bir anlam ve uygulama kazanmıştır. Siyasi liderlerin gücünün ya da otoritesinin yönetim konusunda ya da vatandaşların refahının artırılması konusunda iktidarın belirlenmesi ve insan ve kurumsal yapıların etkileşimlerini doğrudan etkileyen kamu politikaları ile ekonomik ve sosyal kalkınmayı teşvik eden önemli uygulamalar olarak kabul edilmektedir.

\section{YÖNETIME KATILIM OLGUSUNUN TARİHSEL ARKAPLANI VE KAVRAMSAL ÇERÇEVESİ}

Halkın katılımından (Public Participation) neyin kastedildiğini açıklamadan önce, bu konunun neden siyasi tartışmada giderek önem kazandığını açıklamak gerekmektedir. Geçmiş yıllarda diğer konuların yanı sıra büyük altyapı projelerine ilişkin siyasi kararlar, halkın çok daha geniş bir kesimi tarafından tartışılmaya başlanmıştır. Halkın katılımı olmadan üst yönetim tarafından alınan kararlar artık vatandaşlar tarafından kabul görmemeye başlamıştır. Bu tartışma, yeni vatandaş protesto biçimleri politik alana girdiğinde ve demokratik hükümete yeni unsurlar eklendiğinde, 1950'ler ve 1960'larda başlayan temsili demokrasinin değişimi ile ilgili olarak daha geniş bağlamda değerlendirilebilir. Geçmişte olduğundan daha sık olarak siyasi kararların meşruiyeti sorgulanmaya başlanmıştır. Bir taraftan halk kararların alındığı süreçleri eleştirmiş, bu da demokratik meşruiyet eksikliği tartışmasını güçlendirmiştir. Öte yandan, süreçlerin sonuçları da sorgulanarak sonuçların da meşruluğunun eksikliği tartışılmaya başlanarak farklı akademik disiplinlerde incelenmeye başlanmıştır (Rottmann, 2013:6; Kulözü, 2016:84).

Halkın yönetime katılımının kökleri antik Yunan'a kadar gitmektedir. Günümüzdeki katılım konusu ise 1960'lardan önce halkın hükümete katılımı için dışsal süreçlerle geliştirilmiştir. ABD'de 1960'larda Başkan Lyndon Johnson'un büyük toplum programları vatandaş katılımını kurumsallaştırmıştır. 1969'larda vatandaş katılımı, şu anda siyasi ve ekonomik süreçlerden dışlanan vatandaşların kasıtlı olarak geleceğe dâhil edilmesini sağlayan iktidarın yeniden dağıtılması olarak tanımlanmıştır. Kamu sektöründe "açık" problem çözme ile ilgili araştırma gündemini çok önemli hale getirmiştir. Bu sebeple, o zamandan günümüze konu ile ilgili çok sayıda çalışma gerçekleştirilmiştir. Zaman içinde araştırmacılar, farklı araştırma hedefleri takip ederek konu içinde 
farklı konuları çeşitlendirip zenginleştirmişlerdir. Bu çeşitliliğin sonucu olarak halkın karar alma sürecine katılımını tanımlamak için, "yurttaş katılımı", "kamu katılımı", "vatandaş katılımı", "sivil katılım", "halkın katılımı" gibi çeşitli terimler kullanılmıştır. İsim ne olursa olsun, halkın katılımı, demokrasi için "köşe taşı" bir kavram ve vatandaşlar ile kamu yönetimi arasındaki etkin etkileşimi ifade etmektedir. Bununla birlikte, son yirmi yılda doğrudan halk katılımına yönelik talepler, bütün yönetim seviyelerinde ve küresel boyutta artmıştır. Halkın katılımı ile ilgili girdileri ne olursa olsun, katılım ve örgütsel performans arasında pozitif ve anlamlı bir ilişki olduğu belirtilmiş, halkın katılım sürecinde sadece katılımcılar ve yöneticiler ile ilgili kurumlara fayda sağlamadığı aynı zamanda daha geniş bir sosyal değere sahip değerler bütünü olduğu anlaşılmıştır. Katılım, bir sivil hayat olarak değerlendirilmiş, demokratik katılımı derinleştiren ve yönetimi gerçekleştirerek sürdürülebilir kalkınmaya katkıda bulunan bir yapılanma olarak iddia edilmiştir. Bu nedenle halk katılımının toplulukların sürdürülebilir gelişimine katkıda bulunduğu sonucuna varılabileceği kabul edilmiştir (Dutu ve Diaconu, 2017:22). Şeffaflık ve halk katılımı için etik nedenleri hatırlamak da önemlidir. Vatandaşlar, çevrelerini ve yaşam kalitesini etkileyecek kararlar konusunda endişelerini dile getirme hakkına sahiptir. Bu 1998'de imzalanan ve $\mathrm{AB}$ ile üye devletler tarafindan onaylanan Aarhus Sözleşmesinin temelindeki ilkedir ve bilgi erişimi, halkın katılımı ve çevreyle ilgili olarak adalete erişim konusunda birtakım yurttaş hakları tesis etmektedir (Rottmann, 2013:6).

\subsection{Halk - Halk Katılımı Kavramı ve Kapsamı}

Katılım bağlamında halk, "belirli bir mesele ya da konu ile ilgilenen, örgütlü ya da örgütlü olmayan geniş ve heterojen bir grup insan ya da paydaşlar" olarak tanımlanabilir. Daha özel bir katılımcı süreçte tartışılan tanım, paydaş kavramı kullanılarak ve iki kategoriye ayrılarak: Kısmen, ekonomik nitelikli baskı ve çıkar grupları, kısmen de bireyler, çevre ile ilgili sivil toplum kuruluşları, kırsal topluluklar, yerel sakinler, çeşitli eğlence dernekleri, spor ve avcılık gibi vatandaşlar ve sosyo-kültürel çıkar grupları olarak sınıflandırılabilir. Uluslararası sözleşmelerde "kamu" genel olarak "bir ya da daha fazla gerçek ya da tüzel kişi" olarak adlandırılırken, "kamu ilgilisi", kamu tarafından etkilenen ya da kamuyu etkileyen veya çevresel karar verme olarak ifade edilmektedir (Appelstrand, 2018:1). Halkın katılımı, bir kararın etkilenenlerinin karar alma sürecine dâhil olma hakkına sahip olduğuna inanmaktadır. Bir örgütün karar vermeden önce ilgilenen veya etkilenen kişiler, kuruluşlar ve devlet kurumları ile danışması süreci, daha iyi ve daha kabul edilebilir kararlar almak amacıyla iki yönlü iletişim ve işbirlikçi problem çözümüdür (depts.washington.edu). İnternet aracılığıyla halkın karar alma sürecine katılımı kolaylaşmıştır (Sayın ve Yılmaz, 2017:1740). Halkın katılımı, halkı doğrudan ilgilendiren konularda halkın herhangi bir şekilde karar alma sürecine katılması ve alınan kararda kamuoyunun düşüncelerinin göz önünde bulundurulmasıdır. Halkın katılımı tek bir olay değil, bir süreçtir. Bir projenin süresi boyunca ilgili kurum ve kuruluş tarafindan halka bilgi vermek ve onlardan bilgi almak için yürütülen bir dizi faaliyet ve eylemden oluşur. Halkın katılımı yoluyla paydaşlara (bireyler, çıkar grupları, topluluklar gibi bir konuyla ilgilenen veya ilgilendiren kişiler) hayatlarını etkileyebilecek kararları etkileme firsatı tanınır. Kurum ve kuruluşlar, halkın istediğini yapmak zorunda kalacakları düşüncesiyle kamuoyunun taleplerini almaktan çekinmemelidir. Umumiyetle tek bir kamuoyu da bulunmamaktadır. Daha ziyade halk, bir konuda çeşitli görüş ve endişeleri bulunan bir dizi menfaat sahibinden oluşur. Anlamlı halk katılımı yapılırken, bir kamu kurum ve kuruluşu geniş bir yelpazedeki paydaş çıkarlarından gelen girdileri toplayacak, halkın katılımı süreci ile geliştirilen, uygulanan ve kararlarla ilgili olarak, ırk, renk, ulusal köken, cinsel yönelim veya gelirden bağımsız olarak tüm insanlara adil bir muamele ve anlamlı katılım sağlayarak geniş bir bakış açısı ve ilgi sergilemektedir. Kamu kurum ve kuruluşunun görevi, bu görüş ve endişeler arasında dengeyi sağlamak ve kararları halka yansıtarak halkın, çeşitli kaygılarının nasıl değerlendirildiğinin anlaşılmasını sağlamaktır. Tüm halkın katılımı aynı değildir. Halkın anlamlı bir şekilde sürece katılımını sağlamak, karar sürecindeki belirli noktalarda ve bu tür girdilerin karar veya eylemi şekillendirmeye yardımcı olması için gerçek bir potansiyele sahip olması gerekmektedir. Halka basit bir şekilde ne istediğini sormak önemlidir. Bu kadar geniş kapsamlı sorular, beklentileri artırmakta ancak sonuçlar üzerinde doğrudan bir etki bırakmaktadır (www.epa.gov).

Halkın katılımını, bağlı bir uygulama haline getirmek önemlidir ve bir ülkenin siyasi geleneğine, mevzuatına önem verildiğinde ve ulusal seviyede uygulandığında somut bir biçim alacaktır. Bağlı uygulama daha sonra, öznel bir boyutun, örneğin mahalli çıkar ve geleneklerin kavrayışlarına izin vererek, meseleyi ya da çatışmayı başka bir bağlama yerleştirmekte ve farklı bir bakış açısı ile katılım gücünü geliştirmektedir. Sonuçta katılımcı yaklaşım bir sivil toplum diyaloğu işlevini görmeli ve yönetimde toplu ve yapıcı faaliyetlere yol açan karar alma sürecinde bir temel yaklaşım olarak kabul edilmelidir. Katılım hem bir hak, hem bir müzakere hem de belirli seviyede bir karar alma hakkını içermektedir (Appelstrand, 2018:1). Halkın katılımı anlayışında hükümetin rolü nispeten edilgendir. Sadece katılımı tercih eden katılımcılara belli bir derece erişim imkânı sunmaktadır. 
Temsili süreçle birincil kararların verildiği temsili demokrasi bağlamında daha fazla şeffaflık ve katılımın geliştirilmesi amaçlanmaktadır. Etkili mahalli özerkliği artıran yapısal değişiklikleri de içerebilmektedir (Aulich, 2009:46).

Halkın katılımı kavramı, grupların endişelerini dile getiren çevre örgütleri, gençlik kulüpleri veya gençlik kuruluşları gibi lobilerin temsilcileri kadar bireylerin veya vatandaşların inisiyatiflere katılım sürecinde çeşitli paydaş gruplarının, temsil ettikleri grubun endişe ve taleplerini bilinir hale getirmeyi amaçlamaktadır. Lobiciler ve ortak çıkar grupları "organize halk" olarak bilinmektedir. Mümkün olduğunca her türlü katılım süreci tüm paydaşlara ve ilgilenen herkese açık olmalıdır. Bazı durumlarda, mesela ortaya çıkan grubun çok büyük olması durumunda halkın katılımı uygulanabilir olmaktan çıkacaktır. Bu durumda organize halk tüm halkın çıkarlarını temsil edecektir (Arbter vd., 2007:6). Halkın katılımı, geleneksel olarak hükümet faaliyetlerine ilişkin bilgiye kamu erişimini artırmak ve desteklemek için tasarlanan önlemlere odaklanmıştır. Halkın kendilerini ilgilendiren kamusal meselelere ilişkin haklarının genişletilmesine yönelik çabalar ve geniş yurttaşlı̆̆ın adil ve hakkaniyetli temsilinin siyasi sistemlerle gerçekleştirebilmek için katılımcı yönetişim, bu katılımın varsayımlarını ve uygulamalarının gerçekleşmesini engelleyen geleneksel görüşün varsayımlarını inceleyerek derinleştirmeyi amaçlamaktadır. $\mathrm{Bu}$, halkın katılımının daha ayrıntılı ve çeşitli ilkelere, kurumlara ve yöntemlere dayandırılması gerektiğine dair artan bir farkındalığı yansıtmaktadır. Halkın katılımının temeli, siyasi gücün daha eşit dağılımı, kaynakların daha adil dağılımı, karar verme süreçlerinin adem-i merkeziyetçiliği, geniş ve şeffaf bir bilgi alışverişi, işbirlikçi ortaklıkların kurulması, kurumlararası diyaloga vurgu ve daha fazla hesap verebilirliktir. Bütün bu ölçü ve önlemler, stratejik davranış ve aldatmadan çok, güven ve karşılıklılık üzerine dayalı ilişkilere dayanmaktadır (Fischer, 2012:2).

Halkın katılımına ilişkin, kimler katılmalıdır? Katılım nasıl gerçekleşmelidir? Katılmak isteyenlerin etkisi nedir? gibi bir takım sorular bulunmaktadır. Kimin katılacağı sorusu ile ilgili olarak tek tek vatandaşların katılımı yanında çevre dernekleri, sendikalar gibi belirli paydaşlara, yani "organize halk"a atıfta bulunanlar arasında ayrım yapılabilir. Bu konumda her iki gruba da değinilebilir; bireysel olarak bütün vatandaşlar ve organize paydaşlar katılabilirler. Kamu katılımının içeriği ile ilgili tanımların çoğunluğu siyasi karar alma süreçlerine ve (yerel, bölgesel) planlama kararlarına yöneliktir. Resmi ve gayri-resmi katılım arasında ayrım yapılabilir. Bunlardan ilki kanuni olarak gerekli olan katılımcı süreçleri, ikincisi ise kanun tarafından zorunlu olmayan ve dolayısıyla gönüllü olarak yürütülen kamu katılımını ifade etmektedir. Bununla birlikte resmi ve gayri-resmi yöntemleri anlamlı hale getirecek şekilde birbirleriyle bağlantılı hale getirmek önemlidir. Tanımda, gayri resmi katılım terimi, sadece daha geniş kitleleri örgütlü ve şeffaf bir sürece dâhil etmeyi amaçlayan süreçleri ifade etmektedir. Farklı paydaşlar tarafından lobi yapmak gibi siyasi karar alma süreçlerinde yer alan diğer tüm etkileri kapsamamaktadır. Siyasal karar alma süreçlerine yapılan bu katkı gayrı resmi olarak da nitelendirilebilir. Ancak, geniş katılımcı süreçlerden çok daha etkili olan bu siyasal etki biçimi, bu çalışmanın kapsamı ve kamu katılımı konusundaki söyleminin ötesine geçmektedir. Bu tanımların çoğu, paydaşların ve örgütlenmemiş olan tek tek vatandaşların etkileri arasında ayrım yapmaktadır (Rottmann, 2013:6-7). Fung'a (2006:66) göre halkın doğrudan katılımını öngören üç önemli yaklaşım bulunmaktadır. İlk yaklaşım, kimin katılacağıdır. Bazı katılım süreçleri herkese açık iken, diğerleri sadece ilgili grup temsilcileri ve seçkin paydaşlara açıktır. İkinci yaklaşım, katılımcıların nasıl bilgi ve karar alışverişinde bulunacaklarıdır. Pek çok sayıda kamuyu bilgilendirme toplantılarında katılımcılar, yöneticilerden sadece uygulanacak politika ile ilgili bilgi almaktadırlar. Sinırlı sayıda katılımın olduğu toplantılarda ise katılımcılar, nedenlerini, pozisyonlarını ve fikirlerini değiştirebilmektedir. Üçüncü yaklaşım, tartışmalar, politika ya da kamusal eylem arasındaki bağlantıyı tanımlamaktadır. Bu üç yaklaşım, katılımın kapsamı, iletişim ve karar verme şekli ile yetki alanı gibi belirli bir kamu karar mekanizmasının bulunabileceği önemli bir alanı oluşturmaktadır.

Halk katılımı genel olarak; "Politik gelişme için sorumlu kuruluşların veya kurumların gündem belirleme, karar verme ve politika oluşturma faaliyetlerine danışmanlık ve halkın katılımını sağlamak" olarak veya "ilgilenen ve etkilenen şahısların, organizasyonların ve hükümet birimlerinin istişareye ve karar alma sürecine dâhil edilmesine yönelik bir süreç", olarak tarif edilmektedir. Uluslararası Halk Katılımı Birliği (International Association of Public Participation-IAP2)'ne göre, kamu katılımı, bir karardan etkilenenlerin karar alma sürecine dâhil olma hakkının olduğu bir süreçtir. Kamu katılım tanımları aynı temel fikri ifade etmektedir. Bu fikir de kamu kurumlarının karar verme sürecine ilgi duyan kişilerin bu süreçte bir şekilde yer almaları gerekliliğidir (Spijkers, 2014:4).

Neden bir kamu kurumu karar verme sürecine ilgi duyan insanlara, karar verme sürecinde etkin olmas1 gerektiğini öngörmeli veya teşvik etmelidir? Bu sorunun farklı cevapları bulunmaktadır. Gerçekten de, "farklı insanların, halkın katılımının neyi başarması gerektiği konusunda farklı inançları olduğu" ve halkın katılımıyla ilgili farklı alıştırmaların farklı amaçlara hizmet ettiği bir gerçektir. Bununla birlikte, halkın katılımının amaçları 
konusuna açıklık getirmek önemlidir. "Niçin yapıyoruz" konusundaki net açıklama olmadan, uygulamaya konulan halk katılımının herhangi bir etkinliğinin başarısını veya etkinliğini değerlendirmek zordur. Kamu katılımı, doğal olarak önemli kabul edilebilir veya bazı dışsal amaçlara ulaşmak için uygun bir araç olarak faydalanılabilir. Birinci durumda vurgu usul gereklilikleri üzerine kuruludur: Halk katılımının uygulanmasını doğal olarak değerli yapan şey nedir? İkincisinde, vurgu, sürecin sonucudur: kamuoyunun katılımı "daha iyi" kararlar alıyor mu? Kamu katılımı ile kabul edildiğinde kararların uygulanmasını kolaylaştırıyor mu? vb. Eğer halkın katılımı önemli kabul edilirse, toplu katılımın mükemmel organize bir şekilde uygulanması korkunç bir karara yol açarsa sorun teşkil etmez; ve eğer halkın katılımı belirli bir sonuca ulaşmak için uygun bir araç olarak görülürse ve o derece başarıyla sonuçlanırsa, korkunç bir biçimde örgütlenmiş bir toplumsal katılım süreci başarı olarak nitelendirilebilir (Spijkers, 2014:4-5). Toplumsal katılım süreçlerinin uygulanması, toplumsal değerlerin demokratikleştirilmesi ve kamu ihtiyaçlarının daha iyi planlanması ve yerine getirilmesi için önemlidir. Özellikle yönetim geliştirme programlarıyla ilgili olarak halkı eğitmek için de yararlıdır. Bu, potansiyel olarak topluluk üyeleri arasındaki sosyal veya kişisel değişiklikleri etkiler, daha sonra farklı kamu çıkarlarını birleştirmek ve böylece insanların hayatlarını etkileyecek kararlara katılma hakkına sahip olmak için kullanılabilir. Karar verme sürecine katılan halk, gelecekte karar verme sürecindeki rolünün önemini kavrayacaktır. Halkı eğitme ve bilinçlendirmede bir araç olarak hizmet etmekten ziyade, halkın katılımı paydaşların talep ve ihtiyaçlarını daha iyi anlamak için hayati önem taşımaktadır. İlginç bir şekilde, kalkınma planının yapılandırılmasına katılma eylemi, vatandaşların, siyasal ve idari sorunları en aza indirgemesine, diğer yandan da profesyonellerin bulunduğu çevrede şeffaflığın teşvik edilmesine olanak tanır; bu da, iktidar eşitsizliklerine yönelik algıları belirler (Marzuki, 2015:22).

Halkın katılımı, insanların çıkarlarını doğrudan etkileyen politikalar üzerine taleplerini ifade etme isteklerini kuvvetle vurgular. $\mathrm{Bu}$ anlamda, halkın katılımı, "popüler olmayan politikaların uygulanmasının yaygın protestoya ve yönetim organlarına olan güvenin azalmasına neden olabileceğinin pratik bir şekilde tanınmasına" ve böyle bir senaryonun önlenebilmesine dayanır. Bu taleplerin bazı felsefi veya politik teorilere göre haklı olup olmadığı her zaman kamu kurumu için büyük bir soru değildir. Kamu kurumunun halkın katılımına izin vermesinin nedeni, çok daha maddi ve pragmatik nedenlere dayanır: halkın katılım talepleri karşılanmazsa, insanlar sokaklara girer, grev yapar, kuruma geri dönerler ya da hayal kırıklıklarını başka bir şekilde ifade ederler. Halkın bu gibi teşviklerini bastırmak yerine kamu kurumu, halkın katılımını sağlayarak, onları kontrol eder ve yönlendirir. Halkın katılımı bu nedenle lüks değildir; sivil kargaşayı önlemek için bir gerekliliktir. Halkın katılımını organize etmenin önemli bir enstrümantal gerekçesi, vatandaşların ortak olarak davranılmasının politikaların ve planların kalitesini artıracağıdır. İlgilenen kişilerin kamu kurumu ve kendi uzmanlarını tamamlayan belirli pratik tecrübeleri veya bilgi ve fikirleri olabilir. Halkın katılımının gerekçeleri arasında katılımcıların ciddiye alındıklarını hissetmelerine yönelik bir fayda yer almaktadır (Spijkers, 2014:7). Hem özel hem de kamusal alanda, katılım mekanizmaları vatandaşlardan ziyade paydaşların seslerini duyurmalarını ve uygun şekilde karar vermelerini sağlayarak, bir ölçüde meşruiyet ve istikrarı garanti etmektedir. Bu hedefe ulaşmak için politik gruplar ve sivil toplum örgütlerine fikir alış-verişinde bulunmasına izin verilmesi gibi resmi katılım uygulamalarının geliştirilmesine önem verilmesi gerekmektedir (Poto ve Fornabaio, 2017:246).

\subsection{Halk Katılımının Özellikleri ve Temel İlkeleri}

Halk katılımı, kamuoyunun endişelerinin, ihtiyaçlarının ve değerlerinin hükümet ve kurumsal karar alma süreçlerine dâhil edilmesidir. Bu iki yönlü bir iletişimdir ve kamu tarafindan desteklenen daha iyi kararlar almak amacını taşımaktadır. Halkın katılımı ile ilgili tanımların ortak özellikleri şu unsurları taşımaktadır (Creighton, 2005:7);

- Halkın katılımı ile ilgili kararlar idarî kararlar için geçerlidir, diğer bir ifade ile yargısal kararlar ve seçilmiş kişilerin siyasal kararları için değildir.

- Halkın katılımı sadece halka bilgi vermek demek değildir, karar veren kuruluş ile katılmak isteyen kişiler arasında etkileşim bulunmaktadır.

- Halkın katılımı, yanlışlıkla ya da tesadüfen gerçekleşen bir süreç değildir. Toplumu ilgilendiren organize bir süreçtir.

- Katılımcıların kararlar üzerinde farklı seviyelerde belirleyiciliği ya da etkisi bulunmaktadır.

Halkın etki potansiyeline bağlı olarak, halkın katılımının alabileceği farklı biçimler ise şunlardır (www.epa.gov); 
- Sorunları, seçenekleri ve çözümleri anlamalarına yardımcı olacak bilgileri sağlayarak halkı bilgilendirmek,

- Alternatiflerle veya kararlarla ilgili geribildirim almak için halkla istişare etmek,

- Özellikle karar kriterlerinin ve seçeneklerin geliştirilmesinde, karar süreçleri boyunca kaygılarının güvence altına alınmasını sağlamak için halkı dâhil etmek,

- Karar kriterlerini ve alternatiflerini geliştirmek için halkla işbirliği yapmak ve tercih edilen çözümü tanımlamak,

- Nihai karar alma yetkisini ellerine geçirerek kamuoyunu güçlendirmek,

- Arzulanan katılım biçimine bağlı olarak, halkın katılımı için, halkı bilgilendirmek,

- Kamusal girdi oluşturmak ve bazı durumlarda fikir birliği oluşturmak ile anlaşmaya ulaşmak için çeşitli araç ve teknikler kullanılmaktadır.

Birtakım araştırmacılar halk katılımı için prensipler geliştirmişlerdir. Bu İlkeler IAP2 (International Association for Public Participation) tarafından geliştirilmiş ve kısaca şöyle özetlenmiştir (www.doc.govt);

- Halk, üyelerini etkileyebilecek eylemlerle ilgili kararlarda bir söz sahibi olmalıdır.

- Halkın katılımı, halkın katkısının kararını etkileyeceği yönündeki vaadi içermektedir.

- Halkın katılımı, sürdürülebilir kararların tanınmasını sağlayarak, karar veren kurum ve kuruluşlar da dâhil olmak üzere tüm katılımcıların ihtiyaç ve çıkarlarının iletilmesini içermektedir.

- Halkın katılımı bir karar ile doğrudan ya da potansiyel olarak ilgilenen kişilerin katılımını ister ve kolaylaştırır.

- Halkın katılımı, katılımcıların katılımın tasarlanması ile ilgili girdilerin bilinmesini gerektirir.

- Halkın katılımı katılımcılara anlamlı bir şekilde katılmaları gereken bilgileri sağlar.

- Halkın katılımı katılımcılara katılımlarının kararı nasıl etkilediğini bildirir.

Araştırmacıların, halkın katılımı ile ilgili belirlediği değişkenler ise şunlardır (International Peacebulding Advisory Team, 2015:7);

- Siyasi motivasyon ve kaynaklar

- Güvenilen bilgiye erişim ve bunları değerlendirme ve işleme kapasiteleri

- Medya ve medya arasındaki çeşitlilik/rekabetin rolü

- Sivil toplum kapasitesi

- Değişim çabasına geniş katılım

- Güçlü kamuoyu bilgilendirme ve yaygınlaştırma stratejileri

- Devlet-sivil toplum sinerjisi

- Hesap verebilirlik mekanizmasının kurumsallaşması

- İyi davranışları teşvik eden ya da ödüllendiren, kabul edilemez davranışları cezalandıran mekanizmalar.

\subsection{Halk Katılımının Fayda ve Sakıncaları}

Özellikle genel grupları etkileyen kararlarla ilgili olarak vatandaşın sorularına makul cevaplar vermek ve çabalarını dikkate almak halkın katılımını etkilemede önemli kriterler olarak değerlendirilmektedir (Ponce, 2006:275). Katılım, açıklık ve şeffaflık, kamu hukuku alanında karar alma sürecini geliştirebilir. Kamu ve özel sektörlerde aşağıdan yukarıya inisiyatifler "topluma temel güvenlik, ekonomik, sosyal ve politik mallar" sağlamak için yukarıdan aşağıya yönetimle birleştirilmiştir. İyi yönetilen bir sistem, "halkın siyasi katılımı için yeni alanları" geliştiren merkezi düzenlemelerin ve merkezi olmayan uygulamaların bütüncül bir yaklaşımını öngörmektedir (Poto ve Fornabaio, 2017:147). 
Halkın katılımı, siyasi kararların meşruiyetini hem usul hem de esas açısından artırarak bu eleştirinin bir kısmını aşmaya yardımcı olabilir. Eğer süreç, şeffaf bir şekilde işletilmiş ise ve kamuoyunun endişeleri bu yolla giderilebilmiş ise halk sürecin ve kararın adil olduğu sonucuna varılabilir. Kamu katılımının önemli bir nedeni, nihai kararın halkın endişelerini veya bilgisini dikkate alarak iyileştirilebileceği veya muhtemelen onların girdilerini dikkate almayarak zayıfladığı gerçeğidir. Ayrıca siyasal söylemde sıklıkla kullanılan halkın katılımına ilişkin araçsal bir argüman vardır: Daha şeffaf süreçler ve daha iyi siyasi kararlar, bu kararların kabul edilebilirliğini artırır ve bunların uygulanmasını kolaylaştırabilir. Bu açıdan önemli olan erken katılımdır. İnsanlar, ilgili kararlar alındıktan sonra danışıldığını düşünür iseler, bu katılımın meşruiyetini azaltır. Son olarak halkın katılımının tek tek konuların ötesinde olumlu etkileri olabilir. Mahalli politikacılar ya da şirket yöneticileri gibi karar vericiler için kamu güvenini oluşturmak, farklı görüşler için daha iyi bir anlayış oluşturmak ve farklı paydaşların ya da atanmamış halkın siyasi karar verme sürecine dâhil olmasını sağlamaya yardımcı olabilir. Bununla birlikte yeni katılımcı unsurlar çoğu zaman daha iyi eğitimli ve yüksek gelirli vatandaşların etkisinde kalmaktadır. Düşük gelirli ve sosyal olarak dezavantajlı kişilerin katılım eğilimleri daha düşük dolayısıyla etkileri de sınırlıdır. Katılımcı bir sürecin meşruluğu toplumdaki tüm aktörlerin çıkarlarını yansıtmaz ise zayıf olacaktır. Bu nedenle ulaşılması zor olanları dâhil etmek için yaklaşımlar geliştirmek suretiyle bu konuyu ele almak daha da önemlidir (Rottmann, 2013:6-7).

Halkın bakış açısına göre, karar alma sürecine katılma çağrısı, idare tarafından kabul edilmesinin bir işareti olarak görülmektedir. Halk, idarenin plan ve programlarından etkilenmekte ve planlama sürecinde vatandaşların girdilerini teşvik edecek ve planlama sürecinin erken safhasında karar alma sürecine katılmayı kendi çıkarına uygun bulacaktır. Planlar mümkün olduğunca tüm toplumun istek ve çıkarına uygun olmalıdır. Daha geniş anlamda, halkın katılımı sürdürülebilir kalkınmaya yönelik bir anahtardır. Bu kararlar halkın katılımı yoluyla, gelecek nesiller için de yararlı olacak şekilde halkın talep ve ihtiyaçlarına dayandırılacaktır (Marzuki, 2015:22).

CNPPAM (The Committee on National Parks and Protected Area Management) göre halkın katılımının aşağıda belirtilen faydaları bulunmaktadır (www.doc.govt).

- Müşteri beklentilerini ve kullanıcı grup ihtiyaçlarını daha iyi anlayabilme,

- Kamu kurum ve kuruluşu koruma konularını daha iyi anlayabilme,

- Toplumun rolünü ve katkısını artıran kamu kurum ve kuruluşu anlayışı,

- Bilginin daha fazla sürekliliğinin sağlanması,

- Bir proje için topluluk desteği oluşturma ve paydaş ilişkilerini geliştirme becerisi,

- Kamu kurum ve kuruluşlarının sorumluluklarının kamuoyunda daha iyi anlaşılmasının sağlanması,

- Personelin ve toplumun teknik bilgilerinin geliştirilmesinin sağlanması,

- Topluluk içerisinde kurum ve kuruluşun güvenilirliğinin geliştirilmesi,

- Kamu kurum ve kuruluşlarının karar verme sürecinin kalitesinin geliştirilmesi,

- Sosyal sermayenin güçlendirilmesi ve sosyal ve ekonomik faydalar üzerinde akış sağlanması,

- Gelişmiş ve bilgilendirilmiş siyasi süreç,

- Çözümün artan sahipliliği sayesinde daha fazla uyumluluk sağlanması,

- Topluluk becerilerinin artması ve bilgiye daha fazla erişim sağlanması.

Halkın katılımı, uygulamak için güzel ya da gerekli bir şey değildir; aslında daha iyi sonuçlara ve daha iyi yönetişime neden olmaktadır. Anlamlı bir şekilde yapıldığında, halkın katılımı iki önemli fayda sağlayacaktır (www.epa.gov);

1. İlgili kurum ve kuruluşlar, kamu çıkarlarını ve değerlerini yansıtan daha iyi ve daha kolay uygulanabilir kararlar verir ve halk tarafindan daha iyi anlaşılır.

2. Topluluklar, zorlu sosyal sorunları çözmek ve yönetmek için uzun vadeli bir kapasite geliştirir; bu da uzun süredir var olan farklılıkların ve yanlış anlaşılmaların üstesinden gelmektedir. 


\subsection{Halkın Katılımı Yelpazesi (Spektrumu)}

Halkın katılımı, karar veren kurumlar ve halk arasında iletişim fırsatı sağlamaktadır. Bu iletişim, kamu ilgi ve kaygıları için erken uyarı sistemi etkisi oluşturmakta; bunun aracılığıyla doğru ve zamanında bilginin dağıtılması ve sürdürülebilir karar verme sürecine katkıda bulunması için bir araç olabilmektedir. Bu faydalar, halkın katılımı iki yönlü bir süreç olduğunda uygulanmaktadır; Hem kamu kurum ve kuruluşları hem de halk, öğrenebilmekte ve fayda sağlayabilmektedir. Etkili halk katılımı, halkın değerlerinin tanımlanmasını sağlamakta ve nihai olarak onları etkileyen kararlara bu değerler dâhil edilebilmektedir (www.doc.gov.tr). Ayrıca başarılı katılım uygulamaları, mevcut yönetim ve katılım uygulamaları sürecinde iyileştirmeye neden olabilir. Halk, planlar, programlar ve politikalar ile projeler hakkında daha iyi bilgilendirileceklerdir. Kararlar ilgili kişiler hakkında olduğu, sonuçlarının toplumsal kabulü önemli olduğu için halkın katılımı önemlidir. İstek ve kararlarının kabul görmesi vatandaşları mutlu edecek aynı zamanda sosyal entegrasyonu da artıracaktır. Bu durumda katılıma dahil olabilecek kişiler, katılabilecekleri konularla ilgili olarak daha fazla sorumluluk hissedecek ve daha fazla takip gerçekleştirecektir (Nurudin vd., 2015:506). Daha fazla katılım için, halkın katılımı, önerilen tüm kalkınma paydaşları (kamu, hükümet ve sivil toplum örgütleri) arasındaki karşılıklı anlayışı ve ilişkiyi daha da geliştirecek ve idare ile önerilen gelişmenin olumlu bir şekilde desteklenmesini sağlayacak şekilde bilgi alışverişini teşvik edecektir (Marzuki, 2015:22).

Şekil/Tablo 1. Halkın Katılımı Spektrumu (Benefits and Disadvantages of Public Participation; 17/ IAP2's Public Participation Spectrum

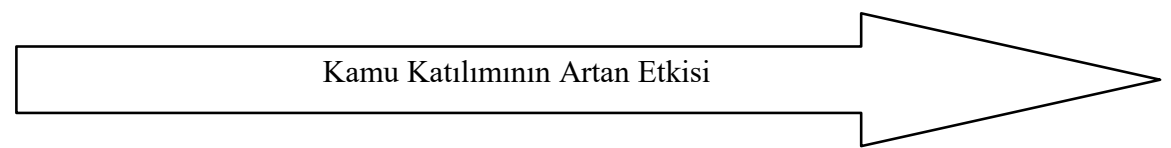

\begin{tabular}{|c|c|c|c|c|c|}
\hline & Bilgilendirme & Danışma & İçerme & İşbirliği Yapma & $\begin{array}{l}\text { Güçlendirme } \\
\text { /Yetkilendirme }\end{array}$ \\
\hline $\begin{array}{c}\text { Halkın } \\
\text { Katılımını } \\
\text { n Amacı }\end{array}$ & $\begin{array}{l}\text { Sorunu anlamasına } \\
\text { yardımcı olmak ve } \\
\text { halka dengeli ve } \\
\text { objektif bilgi } \\
\text { vermek için, } \\
\text { alternatif firsatlar ve } \\
\text { çözümler hakkında } \\
\text { bilgi vermek. }\end{array}$ & $\begin{array}{c}\text { Analizler, } \\
\text { alternatifler ve / } \\
\text { veya kararlar } \\
\text { hakkında } \\
\text { kamuoyunun } \\
\text { görüşlerinin } \\
\text { alınması }\end{array}$ & $\begin{array}{c}\text { Halkın endişeleri ve } \\
\text { isteklerinin tutarlı } \\
\text { bir şekilde } \\
\text { anlaşılması ve } \\
\text { değerlendirilmesi } \\
\text { için süreç boyunca } \\
\text { halkla doğrudan } \\
\text { çalışmak }\end{array}$ & $\begin{array}{l}\text { Kararın her alanında } \\
\text { alternatiflerin } \\
\text { geliştirilmesi ve } \\
\text { tercih edilen } \\
\text { çözümün } \\
\text { belirlenmesi de dâhil } \\
\text { olmak üzere halkla } \\
\text { ortaklık kurma }\end{array}$ & $\begin{array}{c}\text { Halkın nihai kararı } \\
\text { verebilmesini sağlama. }\end{array}$ \\
\hline
\end{tabular}

Kaynak: http://www.iap2.org.au

Planlama ve karar verme süreçlerinde halkın katılımıyla ilgili sayısız avantajlar olsa da, dezavantajlar da vardır. Halkın katılımı zaman alıcı ve bazen pahalı olabilir. Bunu etkili bir şekilde yapmak için, kuruluşlar kapasite geliştirmeli ve personel eğitmelidir. Halkın katılım süreçleri kötü düzenlenirse bu halkta ilgili kamu kurum ve kuruluşuna güven kaybına neden olabilir. Sürecin olumsuz bir tecrübesi, katılımcıların sonucu olumsuz algılamasına neden olabilir ve gelecekteki süreçlere katılma olasılı̆̆ 1 daha düşük olabilir.

\subsection{Halkın Katılımına Yönelik Eleștiriler}

Halkın katılımı demokrasinin temel taşıdır, ancak halkın doğrudan yönetime katılması konusunda derin bir anlaşmazlık bulunmaktadır. Doğrudan demokrasi, toplum hayatını canlı ve kamu kurumlarını da hesap verebilir tutmaktadır. Aralarında çıkan çatışma, devam eden katılımcı bir süreç ve halkın yasa yapmasına yakın bir katılımı ile çözülmektedir. Ama doğrudan katılım arzulanan bir uygulama olsa da uygulanabilir bir uygulama değildir (Roberts, 2004:315). Çoğu insan, bir demokraside, vatandaşların kendilerini etkileyen kararlara katılma hakkına sahip olduğunu kabul eder. Bununla birlikte katılımın usulü konusunda görüş birliği bulunmamaktadır. Yönetim ile ilgili bakış açısı ortak çıkarların belirlenmesi ve gerçekleştirilmesinin seçilmiş yöneticiler ve onların atadığı yöneticiler tarafından gerçekleştirilmesini bekler. Halkın tercihlerinin bilgisi, idari bir yaklaşım için hayati olmakla birlikte, halkın karar verme sürecine, doğrudan katılımı, halkın kendini ilgilendiren stratejik davranışın kapısını açacağından halkın iyiliği için bir tehdit olarak görülmektedir. Çoğulcu yaklaşım, hükümeti, 
halkın yöneticisi değil, çeşitli örgütlü, ortak amaçlar doğrultusunda birleşmiş, belirli kesimleri temsil eden ve belirli kaynaklara sahip olan çıkar grupları (Babaoğlu vd., 2018:71) arasında hakem olarak kabul etmektedir. Çoğulculuğun amacı, tarafsız bir "iyi niyet" değil, ancak örgütlü çıkar grupları arasındaki hür görüş ve müzakereden doğan nispi ortak iyi'dir. Popüler bakış açısı, vatandaşların, politikalar yapılırken, temsilcileri yerine doğrudan katılımını gerektirmektedir. Popüler demokratik teori, demokratik değerlerin vatandaşlara yerleştirilmesinde doğrudan katılımın önemini vurgulamaktadır (Prizzia, 2005:2).

Halkın katılımında iki temel çelişki bulunmaktadır. Bu çelişkiler, bir yandan siyasi çıkarların artırılması ve halkın memnuniyetsizliğinin artması; diğer yandan da resmî önceliklerin bulunmasıdır. $\mathrm{Bu}$ durumu anlayabilmek için, özellikle sosyal politikada kamu katılımının ideolojik, politik ve sosyo-ekonomik ilişkilerine daha fazla odaklanılması gerekmektedir (Newman vd., 2004:203). Ayrıca hem vatandaşların hem de liderlerinin dikkat çektiği gibi, "normal kurumsal kanallarla katılımın, siyasetin özü üzerinde çok az etkisi bulunmaktadır" (King vd., 1998:1). Bu konunun özü, uygun halk katılımını kısıtlayan koşullar konusuna dayanmaktadır. Halkın katılımı olduğunda verimlilik ve etkinlik tehlikeye girebilir. Yürütülen faaliyetlerle ilgili teknik raporlar ve karmaşık planlama konuları ile ilgili çalışmalar halkın bilgisine açıktır. Bu, halkın karar verme sürecini kavrayabilme yeteneğini etkileyecektir. Yerel halkın tüm paydaş gruplarında eşit olarak temsil edilmemesi ya da tüm paydaş gruplarının bir parçası olarak olmaması durumunda etkin halk katılımı elde etmek zordur. Eşit temsil, özellikle önerilen kalkınma ve genel planlamadaki paydaşların bilgi ve anlayışını ifade etmektedir (Marzuki, 2015:22).

Uygulayıcıların, kamu katılımının etkililiği hakkındaki sorulara cevap verebilmeleri bu konudaki başarının tanımını oluşturmaktadır. Bununla birlikte, kamusal katılımın hedefleri hakkındaki perspektiflerin çeşitliliği nedeniyle tek bir tanım geliştirmek sorunludur (Chess ve Purcell, 1999:2685). Bu nedenle halkın katılımının herkes tarafından kabul edilebilecek başarısını değerlendirmek mümkün değildir.

\section{HALKIN KATILIMI VE YÖNETIŞIM}

Yönetişim kavramının nasıl tanımlanacağı konusunda henüz kesin bir fikir birliği bulunmamasına rağmen, kavram, umumiyetle dağıtılmış güç ve otoritenin nasıl kullanılacağını açıklamak ve kararların nasıl alındığı ve vatandaşların karar alma süreçlerindeki katılma derecesini ifade etmektedir. Dolayısıyla yönetişim seçim, karar ve taviz verme ile ve bunların ekonomik, siyasi ve idari yönleri ile ilgilidir. İyi yönetişim, kapsayıcı katılımı sağlamayı, yönetim kurumlarını daha etkin, sorumlu ve hesap verebilir kılmakta ve hukukun üstünlügüne ve uluslararas1 normlara ve ilkelere saygılı olmayı amaçlamaktadır (Wingqvist, 2012:13; Yaman, 2015:114). Yönetişim, gerçekleştiği her türlü sosyal organizasyonda emredici düzenlemelerin, kuralların, kurumların ve uygulamaların sistemlerine atıfta bulunmaktadır. Bundan dolayı yerelden küresele her bütünlük arasındaki ortak yanları oluşturmaktadır (Ruggie, 2014:6).

Özü itibariyle otorite üstünlüğüne ve yaptırımlara dayanmayan yönetim mekanizmalarıdır. Aynı doğrultuda, devletin değişen iç ve dış çevreye uyum sağlamaya çalışması, toplumsal sistemler ve aktörler arasında etkileşim çerçevesi ve devletin bu süreç içindeki rolünü ifade etmektedir. Yönetişim, siyasi aktörler ve kurumlar, özel sektör çıkarları, sivil toplum ve ulus ötesi örgütler gibi farklı yapı, amaç, hedef ve yönelimleri olan aktörler arasında koordinasyon ve uyumun sürdürülmesidir (Yaman, 2015:115). Mecek ve Kocakula (2019:196) yönetişimi;
"yerel, bölgesel ya da ulusal düzeydeki sosyal, siyasal ve ekonomik konularda mevcut olan yönetsel ve politik karar alma yetkisinin salt kamu sektörünün (özellikle devlet idaresi merkezli) tekeline bırakılmadan; bu politikaların ortaya konulması, uygulanması, denetlenmesi ve sürekliliğinin sağlanması sürecinde doğrudan ya da dolaylı olarak etkilenen merkezi idare (devlet), yerel idareler (il özel idareleri, belediyeler, köyler), kamu kurumları, özel sektör kişileri, sivil toplum kuruluşları (STK) ve hizmet alan diğer kişilerin; politik bir denge içerisinde tüm paydaşlarca karşıllklı olarak, birlikte ve birbirleri ile etkileşim içerisinde kullanıldiğl; katılımcı, çoğulcu ve çok merkezli yönetim modelidir",

şeklinde tanımlamıştır. Yönetişim, yatay şebekeler veya kamu, özel ve kar amacı gütmeyen kuruluşlar tarafından, eski hiyerarşik örgütsel karar alma yapılarına karşı çıkan yeni yapılar olarak tanımlanmıştır. "Hükümette, hukuken kurulmuş yetki ve polis gücüne sahip olan birimler faaliyette bulunur. Yönetişim de resmi otorite ve polis gücüne sahip olamayan vatandaşların ve örgütlerin paylaşılan hedefleri tarafindan desteklenen faaliyetlerin oluşturulması, harekete geçilmesi ve uygulanmasına atıfta bulunur". Sonunda düzenlenmiş kural ve toplu eylemler için koşullar yaratmaktadır. Siyasetin ve idarenin çıktıları farklı süreçlerin ürünüdür. Umumiyetle 
yönetişimin "kamu ve özel sektör arasındaki sınırların bulanık hale geldiği yönetim stillerinin geliştirilmesi" anlamına geldiği dönemde tanım üzerinde anlaşmaya varılmıştır. Yönetişimin özü, hükümetin otoritesine ve yaptırımlarına başvurmayacak yönetim mekanizmaları üzerine odaklanmaktır. Bu, çeşitli yönetim birimlerinin ve birbirlerini etkileyen aktörlerin etkileşimidir (Al-Habil, 2011:124). Tek bir merkezin olmadığ 1 ama çok sayıda merkezin olduğu anlamına gelmektedir. Ağların özerkliği önemli olduğundan, egemenlik yetkisine sahip bir güç bulunmamaktadır (Kjær, 2011:101).
"Tüm tarafların kaynaklarl vererek, sorumluluk alarak, yetkilerini kullanarak, siyasaların beklenen sonuçlarının faydalarından yararlanarak sürece dâhil olduğu kamu ve özel veya üçüncü sektör organları arasındaki birlikte karar verme ve ortaklik kriterlerine göre yürütülen politika eylemlerinin geliştirilmesi, belirlenmesi ve uygulanması süreci”,

olarak tanımlanabilir. Yönetişimi normatif bir teorinin önemli bir unsuru olarak yorumlayanlar ile diğer birincil değişkenlerin etkileşiminden kaynaklanan belirli bir süreç sonucunun, bir ürünün tanımlayıcısı olarak tanımlayanları ayırt etmek mümkündür. Devlet, piyasa ve sivil toplum arasındaki ilişkileri birleştirmenin tarihsel olarak belirlenmiş tipik bir yolu olarak değerlendirmektedir. İlk bakış açısına göre, yönetişim belirli değerler, ilkeler ve prosedürler ile karakterize edilen ideal tipik bir model olarak kendini önerme eğilimindedir. Bu eğilimde karar süreçleri belirlenir ve uygulanır. Bu nedenle, yönetişim, açıklık, katılım, sorumluluk, etkinlik, tutarlıl1k, orantılılık ve yerellik açısından iyi yönetişim ilkelerini reçete eden normatif bir teori olarak kendini dayatmaktadır. Diğer bir bakış açısıyla yönetişim, ideolojileri neo-liberal veya neo-keynesyen olanları destekleyen bir fikir olarak yorumlamaktadır. Yönetişim minimal devlet demektir. Her iki bakış açısı da modern toplumları yeni bir rol kavramına yönlendiren bir sürecin sonucudur. Devletin bir yandan vatandaşların değişen ihtiyaçlarını karşılamak ve diğer yandan da vatandaşların oynadığı rol hakkında yeni bir fikir edinmesini sağlamak için "duruşmada" oynamak zorunda olduğu bir roldür. Yaman (2015:115), yönetişime dair beş farklı yorumun bulunduğunu belirtmektedir. Şöyleki;

- İyi yönetişim, şeffaf kamu idaresi, hukukun üstünlüğü, hesap verilebilirlik, güçlü bir sivil toplum ve devlet aktörlerinin sorumluluğu anlamında ekonomik istikrar ve gelişmenin arttırılmasına sağlamaya yönelik etkin siyasi çerçevenin kurulması demektedir. Bu kavram, Dünya Bankası ve diğer uluslararası kuruluşlar ve mali kuruluşlar ihtiyacı olan ülke ekonomileri için kredi politikalarının esaslarını oluşturmaktadır.

- Küresel yönetişim, küresel ticaretin regülasyonu, çevre sorunları, uluslararası barış ve güvenliğe yönelik tehditleri önlemek için devletler ve uluslararası örgütler arasındaki işbirliği biçimlerine işaret eder.

- Kurumsal yönetişim (corporate governance), şirketin kendi işlemlerinde, özel sektörlerdeki şeffaflığı, yönetişimi ve hesap verilebilirliği geliştirmeyi amaçlamaktadır.

- Yeni Kamu Yönetimi, kamu yönetimine ait sektörlerin ve kamu hizmetlerinin tekel niteliğinin sona erdirilmesi, özelleştirilmesi ve ticari yönetim biçimlerinin ve ticari uygulamaların kamu sektörüne dâhil edilmesi demektir.

- Ağlar, çeşitli ortaklık biçimleri ve ağlarla faaliyetlerin koordinasyonu ve yönetilmesiyle alakalıdır. Müzakere ve pazarlık yapan, değiş tokuşu gerçekleştiren ve kendi kendini düzenleyen gayri resmi kurumsal ortamlar olan ağlar, kolektif faaliyet gerektiren sorunların çözülmesine yardımcı olmaktadırlar.

Katılım ile hedeflenen değerlerden birisi de yönetişimdir (Fung, 2015:5). Halkın katılımı, iyi yönetişim uygulamalarının temel taşı olarak kabul edilmektedir. Katılım ya halk tarafından ya da meşru ara kurumlar ve temsilciler aracılığıyla doğrudan iletişim biçiminde olabilir. Buna ek olarak, katılımcılar, seçilmiş ya da atanmış kamu görevlilerinin kararlarından etkilenecek olan kişilerin bu kararları etkilemelerini içerir. Bu nedenle halkın katılımı, kendilerini ilgilendiren meselelerle ilgili olarak idareye vatandaşın katılımıdır. Bu idarenin karar alanındaki vatandaşlara bazı makamların politika oluşturma gündeminin yönetimine katkıda bulunma şansının verilmesi anlamına gelmektedir. Yetkililer, vatandaşların ilgisini çekme konusunda vatandaş merkezli projelerin daha iyi planlanıp uygulanmasına neden olan hizmet talep edenlerin ihtiyaç ve istekleri ile ilgili derhal geribildirim alacaklardır. Bunun yanı sıra, halkın katılımı, kamu kurumlarında iyi yönetişim uygulamalarındaki şeffaflığa da olumlu etkide bulunacaktır (Nurudin vd., 2015:506). Modern yönetişimin çok katmanlı yapısı, en az üç şekilde ve onun karmaşıklığına uygun halkın katılımını içeren kamu katılımı teorisi ve kurumları ile ilgili teorik bilgi içerir. Modern demokratik yönetişimde doğrudan katılımın tek bir biçimi yoktur, çağdaş katılım biçimleri çok farklı şekillerde görülmektedir. Halkın katılımı, çağdaş yönetişimde birden çok amaç ve değeri geliştirir. Toplu kararlar üzerinde eşit etkiye sahip olma ve bireysel özerkliğe saygı gibi ana ilkeler, vatandaş katılımının amaçları ve karakteriyle ilgili yararlı rehberlik oluşturma konusunda çok soyut nitelikte ilkelerdir. 
Katılım mekanizmalarının hedeflediği temel değerleri ve çözmek istediği sorunları incelemek daha verimli sonuçlar almayı sağlayacaktır. Doğrudan katılım mekanizmaları (yaygın olarak tahmin edildiği gibi) siyasi temsil ya da uzmanlığa katı bir alternatif değildir. Aksine onları tamamlamaktadır. Görülebileceği üzere, halkın katılımı, ortak karar alma ve eylemin daha çok arzu edilen uygulama ve sonuçlarını sunmak üzere temsil ve idareyle sinerji içinde çalışmaktadır (Fung, 2006:66).

Günümüzdeki katılım, iyi yönetilen bir sistemin temel unsurlarından biri olarak katılımı ve yönetişimin küresel etkisini araştırmaktadır (Poto ve Fornabaio, 2017:139). Örneğin vatandaşın, AB ilişkilerine katılımına yönelik çıktı odaklı yaklaşımlar, 1990'ların başından bu yana gelişen ve Avrupa entegrasyon araştırmacıları için merkezi bir referans noktası haline gelen yönetişim kavramı etrafında gelişmektedir. Yönetişim kavramını devletten ayıran ve aynı zamanda vatandaşların katılımına olan ilgisini önceden tanımlayan şey, devlet dışı aktörlerin politika yapımında yeniden öneminin artmasıdır. Yönetişim, kamu aktörlerinden ve hiyerarşik karar vermeden kamu ve özel aktörlerin ve hiyerarşik olmayan siyasal yapıların etkileşimine odaklanır. Avrupa Komisyonu geleneksel olarak sosyal paydaşları politika yapma konusunda uzman olarak dâhil etmeye çalışmıştır. Bu çabalar komisyonun Avrupa politikalarını, nispeten dar kaynak tabanına dayandırma ve rızaya dayalı siyasi çözümler ortaya koyma gerekliliğini başlatma hakkına dayanmaktadır. $\mathrm{Bu}$ tür araştırmacılarla ilişkilendirilebilecek katılımcı yönetişim yaklaşımı, gerçek yönetişim oluşturarak katılımcı demokrasiyi gerektirmemektedir (Finke, 2007:6).

Katılımcı teknik, tüm dünyaya yayılmıştır. Çünkü yayılma konusunda umumiyetle diğer yönetişim öncelikleri konusunda güdülenmişlerdir (Fung, 2015:7). Yönetişim ile ilgili ilke kamuya ait olmayan aktörlerin hükümet süreçlerine katılımını meşrulaştırma ilkesi olarak kabul edilmektedir. Bu perspektifte yönetişim, yetki aktarımının siyasi aracı, yani "katılım ve ortak sorumluluk ilkelerinin siyasi arenasında pratik sonuç" olarak kabul edilmektedir. Yönetişim, siyaseti ve vatandaşları siyaset yapımının şekillendirilmesi ve izlenmesinde vatandaşlara ve kurumlara danışmanlık ve katılım yolları oluşturarak uzlaştırmak için uygulanabilir ve demokrasiyi güçlendirecek bir alternatif rasyonalite olarak teşvik edilmektedir. Katılımcı yönetişime özel olarak bakıldığında, iki yönetişim modelinin sınırlamalarına çözüm olarak düşünülmüştür. Bunlarda önemli eksiklikleri hesap verebilirlik ve meşruiyet eksikliği olan piyasa odaklı yönetişim ve ağ odaklı yönetişimdir. "Katılımcı yönetişim" ifadesinde, katılımcı terimi, kamu politikalarının tanımlanmasında, farklı aktörlerin, sivil toplum paydaşları veya organları, katkısı anlamında onu güçlendiren yönetişimi bağlayan bir sıfattır. Fakat karar verme süreçlerinde de birçok risk bulunmaktadır (Marcaletti ve Riniolo, 2015:4).

1990'larda mevcut olan katılımcı düzenlemelerin çoğalması sonucu ortaya çıkan katılımcı yönetişim, yeni mekânlar oluşturmuş ve farklı sivil toplum aktörlerinin bunlara yerleşmesine yol açmıştır. Hem gelişmiş hem de gelişmekte olan ülkelerde bunlar ekonomik ve sosyal kalkınma için daha adil destek biçimleri de dâhil olmak üzere, sorun çözme ve hizmet sunumunda bir takım önemli değişikliklere neden olmuştur. Yol boyunca umumiyetle profesyonel olarak hâkim olandan daha fazla, sık sık yeni sivil toplum örgütleri içerisinde yer alarak vatandaşa veya vatandaş temelli faaliyetlere geçiş anlamına gelmektedir (Fischer, 2012:3).

İyi yönetişimin seviyesi, insanların kalkınma programlarına daha fazla katılımı ile artmıştır. Japonya Uluslararası İşbirliği Ajansları (JICA) iyi yönetişimin, katılımı teşvik etmek ve insanların etkin bir şekilde katılabileceği ortamı oluşturmak için gereken hükümet rollerini sağladığı için katılımcı kalkınmanın temeli olduğunu bildirmiştir. Etkili insanların katılımı, kalkınma çalışmalarının şeffaflığını, uygulama otoritesinin hesap verebilirliğini ve sonuç olarak iyi yönetişimi tesis eden yerel yasalara uyumu artırır. Bu durum, İnsanların katılımını ve iyi yönetişimin birbirinden ayrılmaz olduğunu göstermektedir. Japonya Uluslararası İşbirliği Ajansları (JICA) katılımcı gelişmelerin iyi yönetişimi ve dolayısıyla bir ülkede demokrasiyi desteklediğini gösteren bir diyagram geliştirdiğini belirtmiştir (Waheduzzaman, 2010:41-42).

Yeni sorunların ve yönetişim problemlerinin çözümü için katılım yöntemi kullanılmaya başlanmıştır. Sıradan vatandaşların anayasal bir sorunun çözümüne katıldığı ilk örneklerden birisi 2004 Yılı'nda Kanada British Columbia Vatandaş Meclisi ile başlatılmıştır. O zamandan bu yana sıradan vatandaşların doğrudan taleplerini oylama kuralları ile ilgili konulara ve belirli alanlarda anayasa seviyesinde vatandaş meclisi üyelerini dâhil etme fikri Ontario ve California'da ve kitle kaynaklı anayasa hazırlama süreci ile İzlanda'da da yayılmıştır. Ulusal, bölgesel ve mahalli seviyelerde, vatandaş forumlarının sayısı ve çeşitliliği, sağlı hizmetleri, mali seçimler, şehir ve bölge planlama, ırksal ve etnik çeşitliliği barındıran ve bilimsel ve teknolojik gelişimin zorluklarını ele alan politika alanlarında büyümüş görünmektedir. Özellikle, halkın katılımı meşruiyet, adalet ve yönetişimde etkinlik gibi temel demokratik değerlere ulaşmak için güçlü bir araç olabilmektedir. Bu açıdan kamu aktörleri, karşılaştıkları demokratik zorlukların bir kısmını potansiyel bir çözüm olarak görmelidir. Dikkatle hazırlanmışmanipüle edilmeyen-katılım iyi yönetişimin değerlerini başarmak için etkili bir araç olabilir (Fung, 2015:2). 
Katılımcı yönetişim, mahalli topluluklardaki yetkili kişilerin ortak problem çözme için gerekli olan "sosyal sermaye" türlerini birbirine bağlamasına ve etkinleştirmesine yardımcı olur. Bunu kısmen sosyal güven ve bunu kolaylaştıracak karşılıklı anlayış türünü inşa ederek yapar (Fischer, 2012:4). Her şehirde vatandaşların katılımı, mahalli yönetişimde resmi bir rol oynar ve konsey yapıları içinde resmi bir yer edinir (Blakeley, 2010:138). Halkın katılımı girişimleri birlikte seçme ve birlikte sınırlamanın mümkün olduğu durumlarda gerçekleşebilir. Bunlar iktidar eşitsizliklerinin -yetkililer ve halk arasında, yasal ve gönüllü/toplum kuruluşları arasındamüzakere edildiği durumlardır. Aynı zamanda merkezi ve mahalli yönetişim ile temsilci ve katılımcı demokrasi arasındaki değişen ilişkilerin dinamik bir alanında sık sık yer almaktadırlar. Bu şartlarda işbirlikçi yönetişime yönelik herhangi bir hamle zorlukla karşılaşacaktır (Newman, 2004:218). Düzenleyici müzakereler, mahalli çevre yönetimi ve işbirlikçi planlama olarak tanımlanan bazı yönetişim süreçleri, profesyonel paydaşları bir araya getirmektedir. Bu katılımcılar, düzenli ve organize menfaat sahiplerini ve kamu görevlilerini temsil ederler (Fung, 2006:68).

Genel olarak vatandaş ve hükümet arasındaki etkileşim temelinde geliştirilen üç yönetişim modeli geliştirilmiştir. Bu üç modelin birincisi "İdari Model"dir. Bu modelde insanlar, bilginin pasif alıcıları olarak görülmekte ve yönetim organları, kişilere tek taraflı mesajlar iletmektedir (Waheduzzaman, 2010:42); ikinci model "Danı̧̧manlık Modeli"'dir. Bu Model, idari model ile doğrudan tezattır. Burada bir yönetim organı, insanları bilgilendirmek için bilgi sistemlerini kullanır. Dolayısıyla sistem, insanlar ve devlet arasındaki iletişimi kolaylaştırmaktadır. Chadwick ve May (2003) bu durumu, vatandaşlarla hükümet arasındaki uçurumu azalttı̆̆ için bir "çekme" model olarak tanımlanmaktadır. Son Model, "Katılımcı Model"'dir. Katılımcı Modelde insanlara, hükümet programlarına katılımlarını kolaylaştıran yeterli bilgi sağlanmaktadır. Halkın katılımı için pratik engeller olmadığından, bilgi gücü insanların sivil toplum oluşturmasına yardımcı olunmaktadır. Karar verme sürecine tüm insanlar ya da en azından en fazla sayıda insan katılır. Sinerji ve karşılıklı yardım ruhu, hedefe ulaşmaya yardımcı olur. Buna ek olarak mevcut kullanılan bir yönetişim modeli daha vardır. Bu Model, yönetişimin disipline edici yönünü yansitmaktadır. $\mathrm{Bu}$ Modelde insanlar bilgi ile tam olarak yetkilendirildiklerinde kolektif sosyal programları başlatabilmektedir. Aslında bu model, mahalli yönetim organlarını, son üç modelde mümkün olmayan insanlara daha iyi bir politika sağlamak için zorlamaktadır (Waheduzzaman, 2010:43).

Yönetişim dünyasındaki en önemli aktörler, farklı siyasal katılım biçimleri için yeni alanlar oluşturan sosyal hareketler ve sivil toplum kuruluşları (STK) olmuştur. Resmi hükümet yapıları ile bütün vatandaşlar arasında faaliyet gösteren bu yapılar, sivil toplumun problem çözmede önemli bir yer olarak gittikçe artan önemini vurgulamaktadır. Sivil toplum örgütleri, sosyal hareketlerle vatandaşların ve uzmanların birlikte hareket ettikleri yeni katılım mekanizmaları icat etmişlerdir. Bu icatların bir sonucu olarak, katılım, 1990'larda politik yelpaze genelinde iyi yönetişimin merkezi bir özelliği olarak yer edinmiştir. Adem-i merkeziyetçiliğin teşvik edilmesi, iyi yönetişim uygulamaları, bazı durumlarda hem kaynakların hem de karar verme yetkilerinin aktarılmasına yol açan, giderek karmaşıklaşan kurumsal bir yapıya ek bir mahalli katılımcı kurum katmanı eklemiştir. Hindistan ve Bolivya gibi bazı ülkeler mahalli idarelerde planlama ve bütçeleme dâhil olmak üzere halkın katılımını sağlayan milli bir mevzuat geliştirmişlerdir. Katılımcı yönetişim uygulamaları, devlet ve vatandaşları arasındaki sınırları yeniden düzenleyen, katılımcıların her ikisinden de yeni yollarla birbirlerini meşgul edebilecekleri yeni alanlar oluşturmaktadır. Bu alanlar devletin dışındaki radikal faaliyetler içindir. Aynı zamanda resmi yönetim kurumlarının kapsamını yeniden yapılandırmada da önemli etkilere sahip olabilmektedir (Fischer, 2005:19-21).

Yönetişim, hükümet için vatandaş katılımının geleneksel kavramlarında ima edilen daha pasif rol yerine, mahalli topluluklarda etkinleştirme veya kapasite oluşturma konusunda aktif bir rol içermektedir. Bununla birlikte, hem geleneksel olarak vatandaş katılımı kavramı hem de ortaya çıkan kapasite ve ilişki kurma fikri, vatandaş katılımının çağdaş demokratik toplum ve sürdürülebilir toplumlar için temel yapı taşı olduğu düşüncesi ile ilgili köklere sahiptir. Yönetişimde vatandaş katılımı, güç ve kaynakları merkezin kontrolünden uzağa, alt seviye yöneticilerine, mahalli demokratik yapılara, mahalli müşterilere ve topluluklara devretmeyi hedeflemektedir. Bu demokrasilerde geleneksel yönetimlerin doğrudan vekâlet anlayışında dayanan katılımdan uzaklaşarak, doğrudan müdahaleye yönelen toplulukların karar alma sürecine katılımını içermektedir (Aulich, 2009:45). Hem hükümet faaliyetinde hem de devlet ve toplum arasındaki ilişkilerde yönetişim açısından değişiklikler, katılımı zorunlu bir kriter haline getirmektedir. Birleşmiş Milletler Kalkınma Programı (UNDP), 2002 yılında hazırladığı raporunda yirmi birinci yüzyıldaki insani gelişme stratejisinin, halkla ilişkilerin yönetiminde demokratik yönetim için halkın katılımını gerektirdiğini belirtmiştir. Kamu politikasında vatandaş katılımı, yönetişimin ve dolayısıyla hükümet ve toplum arasındaki ilişkilerin merkezinde ve üç temel boyutta (demokrasi, kalkınma ve haklar) ele alınmalıdır (Mas vd., 2013:71-72). 
Yönetişim, hizmet sağlayıcıları ve müşterileri arasındaki ilişkileri dört ayrı modelde incelemektedir. Bunlardan birincisi olan hiyerarşik yönetişimde ilişkilerin biçimi kurallara dayalıdır. Hizmet sağlayıcılar standartlaştırılmış politika şablonlarını uygulamakta ve yerel topluluklar bu hizmeti almaktadırlar. Burada hizmet sağlama süreci yasal çerçeveler, izleme denetimleri ve değerlendirme ile sınırlandırılmıştır. İkinci yönetişim modeli, idari yönetişimdir. İdari yönetişimde ilişki tarzı, hem hizmet sağlayıcıların hem de alıcıların araçsal olarak harekete geçme ihtimallerinin yüksek olduğu motivasyonel yönetişimdir. Hizmet alıcıları bireysel olarak sözleşme yapmakta ve ortaklaşa hedeflere ulaşmak için teşvik etmektedir. Üçüncü model ise ağ yönetişimi'dir. A $\breve{g}$ yönetişim de ilişkisel iletişim, karşlıklı iletişimin birbirlerine güven geliştirdiği iletişimdir. Burada hizmet sağlayıcılar ve alıcılar arasındaki işbirliği/ağ iletişimi, program uygulamasının dostça bir ortamına dönüşmektedir. Son yönetişim modeli öz yönetişim'dir. Öz yönetişimde hizmet sağlayıcılar, alıcıların kendilerini yönetmelerini kolaylaştırmak için güçlü değerler ve normlar kullanan, ilişki tarzının normatif olduğu yönetişimdir. Gelişmiş örgüt kültürü, mahalli toplulukları kendi programlarını aktif hale getirmeye teşvik etmektedir. Benzer şekilde, halkın katılımı temelinde, yönetişim niteliklerini tanımlamak için araştırmacılar tarafindan dört model geliştirilmiştir. Bunlar; yukarıdan aşağıya uygulama araştırmasına dayanan, katılım için marjinal kapsamı olan ve yönetimden halka doğru ilerleyen bir anlayışı ifade eden "yönetim modeli"; halka danışarak ortak bir gündem geliştirmek için en baştan başlatılan "yasal model-karar verme" süreci; yönetim organı içinde ve topluluk içinde ahenk oluşturan karar verme sürecini açmak için yardım sağlamayı gerektiren "sınırl topluluk katılım modeli" ve toplumun katılımı nedeniyle gerçekleşen "toplumsal güçlendirme modeli" dir (Waheduzzaman, 2010:43).

Demokratikleşmeye yönelik küresel eğilime paralel olarak, yönetişime vatandaş katılımı konusu hem pratik siyaset alanında hem de akademik disiplinlerde artan bir önem kazanmıştır. Yönetişime vatandaş katılımının sağlanması, yönetim kurumlarına halkın güvenini sağlamak, devlet politikalarının insan ihtiyaçlarına göre şekillendirmek ve insanların bu tür politikalarla ilgili gerekli geri bildirimi almak için şarttır. Temsil yoluyla vatandaş katılımına iliş̧in temel kaygılardan birisi kamuoyunun hangi bölümlerinin yönetişimde temsil edildiği ile ilgilidir. Bu bağlamda, demokratik yönetim biçiminde, bu temsilin ırk, sınıf ve cinsiyete bakılmaksızın farklı grupları kapsaması gerektiği vurgulanmaktadır (Haque, 2003:570).

\subsection{Katılım ve Yönetişim Aşamaları Arasındaki İlişki}

Yönetişim, karmaşık bir konudur ve çeşitli tanımları ortaya çıkmıştır. Diğer şeylerin yanı sıra katılımcı, şeffaf ve hesap verebilirdir. Yönetişimin bu üç unsuru (katılım, şeffaflık, hesap verebilirlik) oldukça cazip görünmektedir (Béné ve Neiland, 2006:8). Halkın katılımının ise kendi içinde bir "kamu yararı" olduğu iddia edilmektedir. Halkın katılımı tüm insanların yönetim sistemine katılımının temel bir hak olduğunu kabul etmekte ve tüm halkın gerçek değerini tanımayı ve yönetişim süreçlerine katkıda bulunma becerilerine yatırım yapmay1 gerektirmektedir (International Peacebulding Advisory Team, 2015:7).

Tablo 2. Katılım ve Yönetişim Aşamaları Arasındaki İlişki

\begin{tabular}{|c|c|}
\hline Katılım Aşaması & Yönetişim Modeli \\
\hline $\begin{array}{c}\text { Aşama 1: Yönetim kurumunun karar programlarına başlamadan } \\
\text { once veya uygularken kararını verdiği zaman tek yönlü bir süreç. }\end{array}$ & $\begin{array}{c}\text { Otoriter Model: Bu modelde bir karar en tepeden gelir ve } \\
\text { çognlukla bürokratlar tarafindan uygulanır. Toplam program } \\
\text { süreci şeffaf, hesap verebilir ve öngörülebilir değildir. }\end{array}$ \\
\hline $\begin{array}{c}\text { Aşama 2: İki yönlü iletişime dayanan müşavere, ancak programın } \\
\text { karar verme aşamasında insanların katılımı sınırlıdır. Yönetim } \\
\text { ajansı, insanları geri bildirim alma konusunda bilgilendirmek için } \\
\text { kullanılır, ancak kararları alır ve tek taraflı olarak uygular. }\end{array}$ & $\begin{array}{c}\text { Bürokratik Model: bu modelde insanların katılımı, güç } \\
\text { transferini sağlamak için yeterli değildir. Program süreci daha } \\
\text { az şeffaftır ve daha az tahmin edilebilirdir ve kurum, insanlara } \\
\text { değil üstlerine karşı sorumludur. }\end{array}$ \\
\hline $\begin{array}{c}\text { Aşama 3: Bu aşamada yöneten kurum, sadece karar vermek için } \\
\text { insanları dinlemez, aynı zamanda insanları bütçe dağıtımıyla } \\
\text { meşgul eder ve programı birlikte uygular. Genellikle tüm topluluk } \\
\text { bu sürece dâhil olmaz. }\end{array}$ & $\begin{array}{c}\text { Siyasi Model: Bu modelde insanların katıllımı yeterlidir, ancak } \\
\text { insanlar farklı ilgi grupları arasındaki çatışmaları } \\
\text { evrimleştirebilecek farklı bölümlerdeki kalkınma programlarına } \\
\text { katıllırlar. Yönetim ajans şeffaftır ve bir grup insana karş1 hesap } \\
\text { verebilir ancak tüm topluluğa karş1 sorumlu değildir. }\end{array}$ \\
\hline $\begin{array}{c}\text { Aşama 4: -Güçlendirici - Bu aşamada, yönetim ajansı, insanların } \\
\text { karar ve kaynaklarıyla birlikte kalkınma programlarını ortaklaşa } \\
\text { uygulama kapasitelerini geliştirmelerine olanak tanır. Ajans } \\
\text { kolaylaştırıcı olarak çalışır. }\end{array}$ & $\begin{array}{c}\text { Demokratik model: Bu model, insanlarla ortaklık geliştirmeye } \\
\text { izin verir, karar verme yetkisi verir ve yerel bilgi paylaşımına } \\
\text { sahip bir program uygular. Programın toplam süreci son derece } \\
\text { şeffaf, hesap verebilir ve tahmin edilebilirdir. }\end{array}$ \\
\hline
\end{tabular}


Bu tablo iyi yönetişimin halkı güçlendirmek için sürekli çabalarla gerçekleştirilebileceğini göstermektedir. Bu tablo, iyi yönetişimi elde etmek için bir sonraki adım hakkında net bir gösterge sağlayacaktır. Katılım, belirli bir aşamada yönetişim konumunu belirlemek için bir araç olarak kullanılabilir (Waheduzzaman, 2010:44). Halkın katılımı, iyi yönetişim ve insan hakları değerlerini geliştirmek için tasarlanmıştır.

Çağdaş yönetişimin herhangi bir alanında vatandaş katılımını arttırmanın temel nedeni, genellikle seçilmiş olan karar verici mercilerin seçilmiş temsilciler veya idari görevlilerin bir şekilde yetersiz olmasıdır. Uyum ve işbirliğini yönetmek için gerekli bilgi, olgunluk, kamu amacı, kaynak veya saygıdan mahrum olabilirler. Vatandaşların yönetişime doğrudan katılımının, bu eksiklerin biri veya diğerini düzeltip düzeltmeyeceği katılımı kimin gerçekleştirdiğine bağlı olarak değişir. Önemli olan şey katılanların ilgili grubu ya da halkı uygun bir şekilde temsil edip etmediğidir. Önemli çıkarlar ya da perspektiflerin hariç tutulup tutulmaması, iyi değerlendirme ve kararlar verebilecek bilgi ve ehliyete sahip olup olmaması, katılımcıların katılmayanlara karşı duyarlı ve hesap verebilir olması önemlidir. Bu nedenle, herhangi bir kamu karar verme aygitının birincil özelliği, imtiyazının niteliğidir: Kimlerin katılmaya hak kazandığı ve bireysel katılımcıların nasıl katılımcı olduğu ile ilgili katılım mekanizmalarıdır (Fung, 2006:66).

\subsection{Yönetişimin Niteliklerini Belirlemede Kullanılan Modeller}

Halkın katılımı aşamasına dayanarak, yönetişim niteliklerini tanımlamak için araştırmacılar tarafından dört model geliştirilmiştir. Bunlar (Waheduzzaman, 2007:7-8);

Güç Modeli: Bu model, insanların katılımının birinci aşamada kaldığı, yani bilgi düzeyinde olduğu zaman gelişmektedir. $\mathrm{Bu}$ durumda, kararlar ve kaynaklar en üst seviyeden gelmektedir ve projeler, insanların pasif alıcılar olarak muamele gördüğü katı olarak belirlenmiş süreçleri takiben mahalli ajansın bürokratları tarafından uygulanmaktadır. Yetkililer, umumiyetle mahalli temsilciler veya program hakkında insanları bilgilendirmek için görüntülü bilgi kaynakları ya da mektup kullanarak bilgi sağlamaktadır. Programın toplam süreci, şeffaf, hesap verebilir veya tahmin edilebilir değildir.

Bürokratik Model: Bu model, insanların katılım düzeyinin ikinci aşamada veya danışma aşamasında kaldığı zaman gelişmektedir. Bu modeldeki yönetim kurumları, insanlarla istişarelerde bulunur ve halkın kaynaklarını kullanır. Aancak karar alırken ve politika üretirken onlarla iktidarı paylaşmaz. Katılım, insanların kaynakları hakkında her şeyi bilmelerine izin vermek için yeterli değildir ve bu model yolsuzluk içerir. Umumiyetle istişare için yapılır. Halk, geliştirme aşamasının tüm sürecini paylaşmadıkları için, otorite tarafından müşteriler veya tüketiciler olarak kabul edilir. Program süreci, daha az şeffaf ve daha az tahmin edilebilir. Ancak yönetim örgütü, halka değil de üst yönetime karşı sorumludur.

Siyasi Model: Katılım seviyesi müdahale aşamasına geldiğinde bu model gelişmektedir. Bu modelde kamu yöntemi örgütü, projeyi uygulamak için alacağı kararlarda kaynak ve otoriteyi mahalli halkla paylaşmaktadır. Kamu yönetimi örgütü, bu modelde insanlar ve kurumlar ile her iki tarafın da tarihlerini, ritüellerini, değerlerini ve diğer ortak çıkarlarını paylaştığ 1 için herhangi bir program geliştirmek için iş birliğine dayalı bir koalisyon oluşturur. İnsanlar kalkınma programları ile ilgilendikleri zaman kademeli olarak çatışma gelişebilir. Katılımcılar ortak, oyuncu ya da belli bir şarta bağlı olarak kabul edilebilirler. Ancak ev sahibi ya da mahalli katılımcılar arasındaki güvenin inşası, evrim geçirmiş bölümlenmiş ağ yüzünden zayıf kalabilir. Tahmin edilebilirlik, şeffaflık ve hesap verebilirlik, bu modelde toplum için değil de yüksek seviye yöneticiler için bulunmaktadır.

Demokratik Model: Bu model, insanların katılımının güçlendirme aşamasına ulaşmasıyla yavaş yavaş ortaya çıkmaktadır. Bu model, mahalli bilgi, kaynak ve değerlerin paylaşımı ve karar verme ile uygulama programları hakkında yetki delegasyonu ve ortaklık geliştirilerek sağlanır. Bu model, ortak bir vizyonun gelişimini, ihtiyaçların bütünleşmesini, etkili, verimli ve şeffaf yönetimi, ortak bir çalışma ortamını kolaylaştıran katılımcı planlama ve stratejik karar verme olanağı sağlar. Şeffaflık, hesap verebilirlik ve tahmin edilebilirlik oldukça yüksektir. Sonuç olarak insanlar hizmet eden ya da geliştiren olarak kabul edildiğinde ve buna göre davrandığında bu model en akılcı modeldir. Ancak, yetkililerin bu modelin geliştirilmesini teşvik etmek için esnek ve açık olmaları gerekmektedir.

Halkın katılımı ile ilgili literatürün incelenmesi, iyi yönetişimdeki rolünü kavramsallaştırmak, dolayısıyla katılım aşamalarının, yönetişim modellerinin ve katılımcı araçların karşılıklı olarak birbirine bağlandığını ortaya 
İZCI, Ferit ve SARITÜRK, Mehmet - Demokratik Toplumlarda Halkın Yönetime Katılımı: Yönetime Katılım ve Yönetişim İlişkisi

çıkarmaktadır. Farklı yönetişim seviyeleri için ve bir kurumun aşağıdaki tabloda özetlenebilecek farklı katılım düzeyleri ve katılım araç türlerine ihtiyacı bulunmaktadır (Waheduzzaman, 2007:10-11).

Tablo 3. Halkın Katılımı ve Katılımcı Araçların İyi Yönetişim ile İlişkisi

\begin{tabular}{|c|c|c|}
\hline Katılım Aşaması & Yönetişim Modeli & Katılım Araçları \\
\hline $\begin{array}{l}\text { 1.Aşama: } \\
\text { Bilgilendirme, tek yönlü bir süreç, kamu } \\
\text { kurumu insanlara, kalkınma programlarının } \\
\text { uygulanmasından önce veya uygulama } \\
\text { sırasında kararları bildirdiğinde. }\end{array}$ & $\begin{array}{l}\text { Güç Modeli: Bu modelde bir karar en } \\
\text { tepeden gelir ve çoğunlukla bürokratlar } \\
\text { tarafından uygulanır. Toplam program } \\
\text { süreci şeffaf, hesap verebilir ve tahmin } \\
\text { edilebilir değildir. }\end{array}$ & $\begin{array}{l}\text { Mektup göndermek, mahalli basını } \\
\text { kullanmak, bilgilendirme gecesi, } \\
\text { farkındalık kampanyası, odaklanma } \\
\text { grupları, haber bültenlerini } \\
\text { kullanmak, ekranı kullanmak. }\end{array}$ \\
\hline $\begin{array}{l}\text { 2. Aşama: } \\
\text { Danışmanlık ve çift yönlü bir iletişim } \\
\text { bulunmaktadır. Ancak insanların katılımı } \\
\text { programın karar verme sürecinde sınırlıdır. } \\
\text { Kamu kurumu, geri bildirim alabilmek için } \\
\text { insanları bilgilendirir ve kararı tek başına } \\
\text { alarak uygular. }\end{array}$ & $\begin{array}{c}\text { Bürokratik model: Bu modelde halkın } \\
\text { katılımı, halka güç aktarımı sağlamaya } \\
\text { yetecek seviyede değildir. Program süreci } \\
\text { daha az şeffaftır ve daha az tahmin } \\
\text { edilebilirdir ve kurum, halka değil, } \\
\text { üstlerine karşı sorumludur. }\end{array}$ & $\begin{array}{l}\text { Anket uygulaması, seminer } \\
\text { düzenleme, sergiler ve yorumlar, } \\
\text { belirleyici-önemli kişiler, çıkar } \\
\text { gurubu toplantıları, tartışma } \\
\text { metinleri, halka açık toplantılar, halk } \\
\text { toplantıları. }\end{array}$ \\
\hline $\begin{array}{l}\text { 3.Aşama: } \\
\text { Bu aşamada kamu kurumu halkı karar } \\
\text { almak için sadece dinlemez, aynı zamanda } \\
\text { bütçe dağılımı için halkı dâhil eder ve } \\
\text { programlar birlikte uygulanır. Umumiyetle } \\
\text { toplumun tamamı bu sürece dâhil olmaz. }\end{array}$ & $\begin{array}{l}\text { Siyasi Model: bu modelde halkın katılımı } \\
\text { yeterli seviyededir. Farklı seviyelerde } \\
\text { kalkınma programlarına katılırlar ve bu } \\
\text { programlar çatışmaya neden olabilir. İlgili } \\
\text { kamu kurumu katılım sağlanan gruplar için } \\
\text { yeterince şeffaf ve hesap verebilir nitelikte } \\
\text { olsa bile toplumun bütünü için yeterince } \\
\text { şeffaf ve hesap verebilir değildir. }\end{array}$ & $\begin{array}{l}\text { Topluluk Danışma Komitesi, } \\
\text { Hissedar Danışmanlığı, Müzakereci } \\
\text { Değerlendirmesi, Danışma Kurulları, } \\
\text { Politika Topluluğu Forumu, Kamu } \\
\text { Soruşturması. }\end{array}$ \\
\hline $\begin{array}{l}\text { 4. Aşama: } \\
\text { Güçlendirme, bu aşamada kamu kurumu, } \\
\text { insanların kalkınma programlarını ortaklaşa } \\
\text { uygulamak için kararları ve kaynakları ile } \\
\text { birlikte gelme kapasitesini geliştirmeyi } \\
\text { sağlar. Kurum kolaylaştırıcı olarak çalışır. }\end{array}$ & $\begin{array}{l}\text { Demokratik model: Bu model, insanlarla } \\
\text { ortaklıklar geliştirmeyi, karar verme yetkisi } \\
\text { vermeyi ve mahalli bilginin } \\
\text { paylaşılmasiyla programı uygulamayı } \\
\text { içermektedir. Programın toplam süreci, son } \\
\text { derece şeffaf, hesap verebilir ve tahmin } \\
\text { edilebilirdir. }\end{array}$ & $\begin{array}{c}\text { Müzakereci forum, vatandaş Jürisi, } \\
\text { Topluluk Parlamentoları, Elektronik } \\
\text { Oylama, Referandum. }\end{array}$ \\
\hline
\end{tabular}

Kaynak: Waheduzzaman ve Wahed, 2007.

Yönetişim aktörleri her şey ile ve teori ile aynı anda uğraşmak mecburiyetindedir. Şaşırtıcı olmayacak şekilde, hem mahalli hem milli hem de milletlerarası seviyede kamu politikası süreçlerine ve yönetişimine katılımcı yaklaşımlara karşı direnç bulunabilir. Yaygın olarak kullanılan nedenlerden bazıları şunlardır (International Peacebulding Advisory Team, 2015:2);

- Sıradan insanlar buna zaten ilgi duymazlar çünkü günlük ihtiyaçlarına odaklanmışlardır.

- Sıradan insanlar, meseleleri anlamazlar, bilinçli bir düşünceye sahip olamazlar ve meselenin teknik karmaşıklık seviyesi onların anlayışlarının üstündedir.

- Katılımcı yaklaşımlar çok zaman alır ve karar vermeyi geciktirir.

- Katılımcı yaklaşımlar maliyetlidir.

Yönetişim en iyi teknokratların kontrolüne bırakılabilir. Çeşitli konularda yönetişim ve kamu politikası, uzmanlık bilgisi gerektirir ve bu nedenle sıradan vatandaşın elinde bırakılmamalıdır. Uzmanlar, profesyoneller ve teknokratlar için önemli bir konudur. Halkın katılımı ise seçmenler ve seçilmiş kurumlar arasındaki mesafeyi daraltmak için tasarlanmıştır. Demokrasinin kalitesi, yönetişimin tüm alanlarında geçerli olan halk katılımının boyutu ile doğrudan ilişkilidir (International Peacebulding Advisory Team, 2015:7). 


\subsection{Katılımcı Yönetişim}

Katılımcı yönetişim, halkın sesini siyasi karar verme sürecine resmi olarak ulaştırması olarak tanımlanabilir. Devlet merkezli karar verme otoritesinin devlet ve vatandaşın birlikte karar oluşturacak şekilde yeniden oluşturulması anlamına gelmektedir. Katılımcı yönetişim kurumları, geleneksel temsili liberal demokrasi kurumlarının yerini almaktan çok, tamamlayıcı olmak üzere tasarlanmıştır. Kamu kararlarını politika sürecine dâhil eden resmi yapılarının geliştirilmesi ile karakterize edilen kurumsal çözümlere vurgu yapmaktadır (Johnson, 2013:2-3). Kamu ve özel sektörler arasında destekleyici ișbirlikçi temelli söylemsel ilişkileri kolaylaştıran siyasi ağlar ve kurumsal düzenlemeler yoluyla hükümet dışı bireyleri ve örgütleri meşgul etmenin yollarını da içermektedir (Fischer, 2012:2).

Siyasi karar alma sürecinde, kamuoyunun, devlet tarafından onaylanan doğrudan katılımı olan katılımcı yönetişim giderek yaygınlaşmıştır. İhtiyatlı tahminler, Brezilya'da sadece 2 Milyar dolarlık kamu parasının katılımcı süreçler yoluyla tahsis edildiğini gösterirken, 2008 yılı itibariyle, Avrupa'da 100 farklı şehir, vatandaşların doğrudan şehir bütçesinin önemli bölümlerini belirlemesine karar vermiştir. Avrupa'dan şehir plancıları, Brezilya ve Hindistan'daki konferanslara katılarak, topluluk seviyesinde kararların adem-i merkezileştirilmesinin yeni yöntemlerini öğrenmektedir (Johnson, 2013:1). Katılımcı yönetişim, kamu işlerini yürütmenin sadece hükümet ve kamu idaresinde değil, devlet kurumları ile sivil toplum grupları arasında işbirliğini de içeren düzenleyici bir çerçeve olarak tanımlanmaktadır. Benzer şekilde "birlikte yönetişim" aynı düşünce ve farklı terminolojiyi kullanıyor olsa da "kamu politikasının oluşturulmasında ve uygulanmasında, kamu-özel politika ağlarının birleşiminde, devlet ve toplumsal grupların birbirine kenetlenmesi" olarak tanımlanmıştır. Her iki tanımda da hükümetlerin düzenli vatandaş gruplarını politika yapma ve uygulamaya dâhil ettiği düzenlemeleri öngörülmektedir. Fakat özellikle hükümetler, seçimde en çok oyu almış olmalarına rağmen, vatandaşı karar verme sürecine neden dâhil etsin? Bunun bir dereceye kadar örtüşen iki sebebi bulunmaktadır. Katılımcı yönetimin savunulmasının yanında aralarındaki fark genellikle kaybolmaktadır. İlk olarak, hükümetler, hükümet hedeflerine yönelik aktif desteğin elde edilmesi için gerekli olan örgütlü özel seçimler olmadan hedeflerinin gerçekleşmeyeceğinin farkına varabilirler. Gerekli işbirliğini güvence altına almak amacıyla, bu seçimlerin temsilcilerini politika yapma ve uygulanmasını izleme sürecine katılmaya davet etmektedirler. Katılımdan açık ya da örtük beklenti, katılıma davet edilen kuruluşların taraf oldukları kararları destekleyecekleri ve seçmenleri kararlar doğrultusunda ikna edecekleridir. Bu düzenlemeler, s1k s1k "sosyal ortaklık" ve ortak çıkar için işbirliği gibi değerleri artırmak ve örgütlü çıkar gruplarının direncini önlemek ve işbirliğini teşvik etmek için pragmatik araçlar olarak kullanılmaktadır. Katılımın bu biçimi klasik olarak korporatizm ya da "uyuşma" olarak adlandırılır ve tanıdık uygulaması üç taraflı hükümet -emek- iş formudur. $\mathrm{Bu}$ modelin yapısını oluşturanlar tek tek belirleyici olmaktansa birlikte karar alır ve uygularlar. Bu yapı, daha ziyade söz konusu konularda resmi olarak onaylanan kanallardaki hükümete ve diğer kilit aktörlere doğrudan bildirme ve onlara siyasette güvence verme firsatı oluşturmuştur. Amaç demokrasiyi genişletmek ve derinleştirmek değil, daha yumuşak hükümet sağlamaktır (Friedman, 2006:14).

Katılımcı yönetişimin bir diğer gerekçesi, hükümet kararlarını vermede veya etkilemede görev alan vatandaşların yelpazesini genişleterek demokrasiyi genişletip derinleştirmektedir. İfade edilen ya da ima edilen bir mantığa göre, demokrasi, temelde, siyasi toplumun tüm üyelerinin kamu işlerinde eşit bir söz hakkına sahip olduğu halk egemenliğinin ifadesidir. Oy vermek katılımın garantisi değildir, çünkü belirli bir parti için oylama herhangi bir politika pozisyonuna destek olarak otomatik olarak yorumlanamaz ve seçimler arasında katılım fırsatını en üst düzeye çıkarmak için demokrasiler gereklidir. Burada katılımın anlamı "sesi olmayan" vatandaşların sesi olmasıdır. Amaç, hükümetin işbirliğine ihtiyacı olanları yönetmek ve yönetişime katılan vatandaşların katılım yelpazesini genişletmenin normatif amacını yerine getirmesini sağlamak için araçsal olarak katılımın kullanılması değildir. Katılımcı yönetişimin birçok normatif savunucusu yönetişimi, bir geliştirme aracı olarak vurgulamaktadır. Böylece katılımcı yönetişim, etkili kamu yönetimi için bir araç olarak kabul edilmenin dışında, genellikle kalıcı ve sürdürülebilir kalkınma için bir ön koşul olarak görülmektedir. Katılımcı yönetişimi değerlendirmeye yönelik girişimler iki rasyonelliği bozmaya ve bu nedenle temel noktayı kaçırmaya meyillidirler. Bu çoğu zaman, kurumsallaşma tartışıldığı zaman olur. Eleştirmenler, yalnızca organize edilenlerin masada olmasından şikâyet eder. Ancak, eğer gerekçe, hükümet kararlarını örgütlü çıkarlar ile anlaşmaya vararak uygulama konusunda daha yetenekli hale getirmek, o zaman sadece örgütlü irade devreye girecektir. Eğer demokrasiyi derinleştirmek için bir araç yerine, pragmatik yönetim stratejisi olarak korporatizmi ya da diyalog ve birlikte karar vermeyi 'concertation' anlıyorsak ilgili soru toplumdaki tüm grupların temsil edilip edilmediği değil, siyasi işleyişi bozabilecek örgütlü grupların temsil edilip edilmediğidir. Demokrasilerde vatandaşlar, katılımcı yönetişim kurumlarında bulunmanın yanı sıra kamuoyunu etkileme imkânlarının 
geliştirilmesini ve bunu kullanmayı isterler. Böylece katılımcı yönetişimci yapılardan uzak olmaları siyasi tartışmalara seyirci kalmaları ile sonuçlanmaz. Gerçekten de bu forumlar, duyulması için firsat olarak görülmez ve siyasetin sorumluluğunu üstlenmenin bir yolu olarak görülürse, o zaman bazıları taraf olmamayı tercih edebilir. Çünkü bu, ortak sorumluluğun gerektirdiğini kabul etmek anlamına gelecektir. Eğer korporatizm uygun olmayan kriterlerle değerlendirilirse, işlevini yerine getirip getirmediğini, yani örgütlü sosyal aktörler arasında uzlaşma sağlama görevini yerine getirip getirmediğini değerlendirmek imkânsız hale gelir. Daha ince bir değerlendirme ile vatandaşların düşünce ve isteklerini ifade etme firsatı oluşturmayı hedefleyen katılım biçimleri hakkında da yanlış bildirimler olduğu görülmektedir. Örgütlü grupların katılımı için bir araç olarak katılımcı yönetişime baktığımızda, burada belirtilen tanımların aksine, "paydaşların" veya "topluluk gruplarının" forumlara çekilmesine vurgu yapılmaktadır (Friedman, 2006:15-16). Ancak amaç uygulanabilir anlaşmalara ulaşmak yerine demokrasiyi derinleştirmektir. Bu yüzden, bu mekanizmaların uygulanması gerekir. Bu uygulanmaz ise sürecin dışında kalan vatandaşların sessizliği ya da katılamaması onlar için katılım olacaktır. Örgütlü çıkarlar, katılım sürecine dâhil olur ise katılım yelpazesini genişletmektedir. Bu çıkarlar örgütlenmez iseler bireysel çıkarlara dönüşürler ve nadiren katılım sürecine dâhil olurlar. Demokratikleştirici rolünü vurgulayan katılımcı yönetişim yaklaşımları ile genellikle örgütlü grupların toplumsal sessizliğe sesler verdiği varsayılmaktadır. Forumlar, örgütlenmiş çıkarlar katılımı için sıkı şekilde yapılanmış firsatlar oluşturmaktadır. $\mathrm{Bu}$ şekilde sisteme katılmayan çıarlar zayıf ve çeşitli yollarla sisteme katılacak ve bu da demokrasiyi genişletmeyecektir. Yönetişimci katılımın mantığı örgütlü seçmenin isteklerini politik sonuçlara dönüştürmek ya da toplumsal sessizliği sese dönüştürmek siyasal ve idari sonuçlar elde etmektir (Friedman, 2006:15-16).

Dünyanın çoğu yerinde siyasi kurumlara duyulan güven ve azalan seçmen katılımı siyasi katılımın azaldığını göstermektedir. Hükümetler bu eğilimlerin sorunlu olduğu sonucuna vardılar ve kendi politikalarının oluşumuna katılan vatandaşların sayısını artırarak yönetişim ağını genişletmeye ve yönetişime katılan vatandaşların sayısını artırmaya çalışmışlardır (Komito, 2005:39).

\section{SONUÇ}

Siyasal sistemin devamını sağlayabilmek için halkın katılımı önemlidir. Bütün siyasi yapılar için katılım önemlidir. Modern toplumsal ve siyasal yapılar katılım ile ilgili mekanizmalar geliştirmişlerdir. $\mathrm{Bu}$ mekanizmalar, ideolojilere göre farklılıklar oluşturmasına rağmen demokrasinin tabiatında var olan farklılık ve çatışma özellikleri içinde sistemden daha fazla pay almayı hedefleyen bir kültüre dayanmaktadır. Avrupa ve Amerika'nın toplumsal yapısı ve siyasal kültürünün temeli olan rekabet güç eşitsizlikleri içinde sistemin devamını tehlikeye atan yapısal sorunlar üretmekte ve bu durum yeni düzenlemelerle aşılmaya çalışmaktadır.

Amerika Birleşik Devletleri’nde II. Dünya Savaşı'ndan galibiyetle çıkmanın etkisi ile ortaya çıan ekonomik sonucun paylaşmayı kolaylaştırıcı büyüklüğü ve doğu bloku örneğinin kültürel ve siyasi baskısı toplumun alt ve aşağ tabakalarının sisteme daha fazla entegre olmasını ve sistemin güvenliği daha az tehdit etmesini mümkün hale getirecek bir yol olarak katılım konusundaki akademik ve kanuni çalışmaları hızlandırmıştır. Daha sonra aynı ülkelerin hegemonik gücünün etkisi ile yönetişim uygulamalarında olduğu gibi, yaygınlaştırılmıştır.

Yönetişim, neoliberal uygulamaların bir parçası ile parçalanan devlet gücünün sonucu olarak karar alma sürecine yeni aktörlerin dâhil olmasıdır. Bunlar özel sektör ve sivil toplum kuruluşlarıdır. Yönetişim bir yönetime katılma mekanizması olarak kabul edilebilir. Bütün siyasal yapıların tabiatında var olan katılımın postfordist dönemde ortaya çıkan grubu yönetişimin esaslı bir türüdür. Halkın katılımı ise tek tek kişilerin katılımının yanında grupların da katılımını içerir ve planlamadan denetlemeye kadar her aşamada gerçekleşir. Bu nedenle halkın katılımı yönetişimi kolaylaştırıcı bir etkiye sahiptir.

Yönetişim ve halkın katılımı mahiyeti itibariyle işleyişin demokratikleşmesini güçlendirir. Halkın katılımı kavramı, çok eski olmasına rağmen, 1950'li yıllarda ABD'de de ortaya çıkarak yaygınlaşmaya başlamış liberal bir anlayışı ve uygulamayı ifade etmektedir. Yönetişimi kolaylaştırıcı ve yaygınlaştırıcı bir etkiye sahiptir. 


\section{KAYNAKÇA}

ADEOSUN, A. Babatunde (2012), "Nigeria@50: The Role of Good Governance And Effective Public Administration Towards Achieving Economic Growth And Stability in Fledgeling Democracy", International Journal of Politics And Good Governance, S.3(3), ss.1-17.

AL-HABIL, Wasim (2011), "Governance And Government in Public Administration", Journal of Public Administration And Policy Research, S.3(5), ss.123-128.

APPELSTRAND, Marie (2003), "Public Participation And Collaboration", Publication Series of The Institute of Forest Sector Policy And Economics, S.48, http://www.metla.fi/eu/cost/e19/appelstrand.pdf (Erişim Tarihi: 31.01.2018).

ARBTER, Kerstin, HANDLER, Martina, PURKER, Elisabeth, TAPPEINER, Georg ve TRATTNIGG, Rita (2007), The Public Participation Manuel, ÖGUT (Austrian Society for Environment and Technology), Vienna.

AULICH, Chris (2009), "From Citizen Participation to Participatory Governance in Australian Local Governance", Commonwealth Journal of Local Governance, S.2, ss.44-60.

BABAOĞLU, Cenay, ÇOBANOĞLU, Sedat ve GÖÇOĞLU, Volkan (2018), "Kamu Politikalarına Sivil Katılımda Farklı Bir Model: Rusya Federasyonu Sivil Kamarası", Süleyman Demirel Üniversitesi İktisadi ve İdari Bilimler Fakültesi Dergisi, S.23(1), ss.69-77.

BÉNÉ, Christophe ve NEILAND, Arthur (2006), From Participation to Governance: A Critical Review of The Concepts of Governance, Co-Management And Participation, And Their Implementation in Small-Scale Inland Fisheries in Developing Countries, World Fish Center, Penang, Malaysia, CGIAR Challenge Program on WATER \& FOOD, Colombo, Sri Lanka, 72p.

BLAKELEY, Georgina (2010), "Governing Ourselves: Citizen Participation And Governance in Barcelona And Manchester", International Journal of Urban And Regional Research, S.34(1), ss.130-145.

CHESS, Caron ve PURCELL, Kristen (1999), "Public Participation And The Environment: Do We Know What Works?”, Environmental Science \& Techonology, S.33(16), ss.2685-2692.

CREIGHTON, James L. (2005), The Public Participation Handbook, Making Better Decisions Through Citizen Involvement, Jossey Imprint, San Francisco.

DOĞAN, Kadir Caner (2017), "Postmodern Kamu Yönetiminin Kuramsal Temelleri Çerçevesinde Yönetişim Yaklaşımı: Literatür Taraması”, Ömer Halisdemir Üniversitesi İktisadi ve İdari Bilimler Fakültesi Dergisi, S.10(1), ss.27-45.

DUTU, Amalia ve DIACONU, Mihaela (2017), "Community Participation for an Open Public Administration: Empirical Measurements And Conceptual Framework Design", Cogent Business \&Management, S.4, ss.1-22.

FINKE, Barbara (2007), "Civil Society Participation in EU Governance", Living Reviews in European Governance, S.2, ss.1-31.

FISCHER, Frank (2005), "Participatory Governance as Deliberative Empowerment The Cultural Politics of Discursive Space", American Review of Public Administration, S.36(1), ss.19-40.

FISCHER, Frank (2012), "Participatory Governance: From Theory to Practice", The Oxford Handbook of Governance (Ed. David Levi Faur), Oxford Handbooks Online, ss.1-18.

FRIEDMAN, Steven (2006), "Participatory Governance And Citizen Action in Post-Apartheid South Africa", International Institute for Labour Studies, Discusion Paper Series, Geneva, ss.1-34.

FUNG, Archon (2006), "Varieties of Participation in Complex Governance", Public Administration Review, S.Specail Issue, ss.66-75.

FUNG, Archon (2015), "Putting The Public Back into Governance: The Challenges of Citizen Participation And Its Future", Public Administration Review, S.75(4), ss.1-10. 
İCİ, Ferit ve SARITÜRK, Mehmet - Demokratik Toplumlarda Halkın Yönetime Katılımı: Yönetime Katılım ve Yönetişim İlişkisi

HAQUE, M. Shamsul (2003), "Citizen Participation in Governance Through Representation: Issue of Gender in East Asia", International Journal of Public Administration, S.26(5), ss.569-590.

IKEANYIBE, Okey Marcellus, ORI, Ogbannaya Eze ve OKOYE, Arinze Emmanuel (2017), "Governance Paradigm, in Public Administration And The Dilemma of National Question in Nigeria", Cogent Social Sciences, S.3, ss.1-16.

INTERNATIONAL PEACEBULDING ADVISORY TEAM (2015), "Public Participation And Citizen Engagement", Effective Advising in Statebuilding And Peacebuilding Contexts- How, Geneva İnterpeace, Geneva.

JOHNSON, Carolina (2013), "Diverging Models of Participatory Governance: A Framework for Comparison", Western Political Science Association Meeting, Holywood, CA, WPSA 2013, ss.1-24.

KING, Cheryl Simrell, FELTEY, Kathryn M. ve SUSEL, Bridget O'Neill (1998), "The Question of Participation: Toward Authentic Public Participation in Public Administration", Public Administration Review, S.58(4), ss.317-326.

KJÆR, Anne Mette (2011), “Rhodes' Contribution to Governance Theory: Praise, Critisim And Future Governance Debate", Public Administration, S.89(1), ss.101-113.

KOMITO, Lee (2005), "e-Participation And Governance: Widening The Net", The Electronic Journal od eGovernment, S.3(1), ss.39-48.

KULÖZÜ, Neslihan (2016), "Participation as a Meansto an Endor as an End in Itself: The Success Evaluations of Participations", Turkish Public Administration Annual, S.41-42, ss.83-102.

LADI, Stella (2008), "Good Governance And Public Administration Reform in The Black Sea Economic Cooperation (BSEC) Member States", Xenophon Paper No:6 International Centre for Black Sea Studies (ICBSS), Athens, Greece.

MARCALETTI, Francesco ve RINIOLO, Veronica (2015), "A Participatory Governance Model Towards The Inclusion of Ethnic Minorities. An Action Research Experience in Italy", Revue Interventions Économiques, S.53, ss.1-18.

MARINETTO, Mike (2003), "Governing Beyond The Centre: A Critique of The Anglo-Governance School", Political Studies, S.51, ss.592-608.

MARZUKI, Azizan (2015), "Challenges in The Public Participation And The Decision Making Process", Sociologija i Prostor, S.201(1), ss.21-39.

MAS, Joaquin Tornos, DIEZ, Alfonso Arroyo, MARTINEZ, Mar Martinez ve PAGÁN, Juana López (2013), Transparency, Accountability And Participation: A Common Agenda for Social Cohesion And Governance in Latin America (Ed. Jordi Castells, Octavi de la Varga, Eduardo Feldman, Sara Sotillos, Carla Cors, Verónica Sanz), URB-ALL Programme, Barcelona.

MATHEBUlA, Ntwanano E. (2016), "Community Participation in The South African Local Government Dispensation: A Public Administration Scholastic Misnomer", Bangladesh e-Journal of Sociology, S.13(1), ss.18-28.

MECEK, Mehmet ve KOCAKULA, Özge (2019), "E-Devlet ve E-Yönetişimde İdari, Siyasi ve Etik Sorunlar", E-Yönetişim: Kavramsal/Kuramsal Çerçeve, Ülke İncelemeleri ve Türkiye'ye Yansımaları (Ed. Bekir Parlak ve Kadir Caner Doğan), Beta Yayınları, İstanbul, ss.195-230.

NEWMAN, Janet, BARNES, Marian, SULlIVAN, Helen ve KNOPS, Andrew (2004), "Public Participation And Collaborative Governance", Jnl Soc., Pol., S.33(2), ss.203-223.

NURUDIN, Suzie Mat, HASHIM, Rugayah, HAMIK, Saidatul Akma, RAHMAN, Shamsinar, ZULKIFLI, Nursyahida, MOHAMED, Ahmad Shah Pakeer (2015), "Public Participation Process at Local Government Administration: A Case Study of The Seremban Municipal Council, Malaysia" 2nd Global Conference on Business and Social Science, GCBSS-2015, 17-18 September, Bali, Indonesia, Social and Behavioral Sciences, S.211, ss.505-512.

PONCE, July (2005), "Good Administration And Administrative Procedures", Indiana Journal of Global Legal Studies, S.12(2), ss.551-588. 
POTO, Margherita Paola ve FORNABAIO, Lara (2017), "Participation as The Essence of Good Governance: Some General Reflections And a Case Study on The Arctic Council", Arctic Review on Law And Politics, S.8, ss.139-159.

PRIZZIA, Ross (2005), "Community Involvement in Protecting The Environment: The Role of Restoration Advisory Boards (RABs)" The Innovation Journal: The Public Sector Innovation Journal, S.10(1), ss.1-16.

ROBERTS, Nancy (2004), "Public Deliberation in an Age of Direct Citizen Participation", American Review of Public Administration, S.34(4), ss.315-353.

ROTTMAnN, Katja (2013), "Recommendations on Transparency And Public Participation in The Context of Electricity Transmission Lines", E-Artikel, https://germanwatch.org/de/download/8649.pdf (Erişim Tarihi: 31.01.2018).

SAYIN, Ahmet Kenan ve YILMAZ, Vedat (2017), "Halkla İlişkiler Toplumu ve Güvenlik Hizmetleri, Toplum Destekli Polislik Örneği”, Social Sciences Studies Journal, S.3(11), ss.1739-1748.

SPIJKERS, Otto ve HONNIBAL, Arron (2014), "Developing Global Public Participation (1): Global Public Participation at The United Nations 1 Otto Spijkers And Arron Honniball", E-Article, ss.1-21, https://acuns.org/wp-content/uploads/2013/01/Otto-Spijkers-Global-Public-Participation-at-The-UnitedNations-15-5-2014.pdf (Erişim Tarihi: 31.01.2018).

ŞAHİN, İsmail (2014), "Governance Tools in Public Administration And Emergent Trends: Contracting, Citizen Participation, And Networks", International Journal of Human Sciences, S.11(2), ss.10821103.

THOMPSON, Lisa (2007), Participatory Governance? Citizens And The State in South Africa, African Centre for Citizenship \& Democracy, University of The Western Cape.

WAHEDUZZAMAN, Wahed (2010), "People's Participation for Good Governance: A study of Rural Development Programs in Bangladesh", Basılmamış Doktora Tezi, Victoria Üniversitesi, ABD.

WAHEDUZZAMAN, Wahed (2007), "Conceptualizing People's Participation for Good Governance", 21st Australian And New Zealand Academy of Management Conference (ANZAM 2007), 4-7 December, Sydney - Australia.

WINGQVIST, Gunilla Ölund, DRAKENBERG, Olof, SLUNGE, Daniel, SJÖSTEDT, Matin ve EKBOM, Anders (2012), The Role of Governance for İmproved Environmental Outcome, Perspectives for Developing Countries And Countries in Transition, Swedish Environmental Protection Agency Report 6514.

YAMAN, Emrah (2015), “Yönetişim Sürecinde Devletin Rolü ve Deniz Ticaret Sektörü”, İGÜSBD, S.2, Sayı:2, ss.111-133.

http://www.doc.govt.nz/Documents/science-and-technical/sfc308a.pdf , "Benefits And Disadvantages of Public Participation", (Erişim Tarihi: 31.01.2018).

http://www.iap2.org.au/Tenant/C0000004/00000001/files/IAP2_Public_Participation_Spectrum.pdf ， “IAP2's Public Participation Spectrum", (Erişim Tarihi: 31.01.2018).

https://www.epa.gov/sites/production/files/201405/documents/ppg_english_full-2.pdf, "Introduction to The Public Participation Toolkit", (Erişim Tarihi: 31.01.2018). 